\title{
The Home that the Woman's Building Built: Cheri Gaulke and Sue Maberry Construct a Visual Narrative of the Lesbian Family
}

\author{
ANNE SWARTZ \\ Savannab College of Art and Design, Savannah, Georgia, USA
}

\begin{abstract}
Artists Cheri Gaulke and Sue Maberry's feminist activism learned at the Woman's Building, combined with their lesbianism, radicalized them to create ongoing documentation of their family. This article examines how Gaulke has intertwined her domestic, private imagery and narrative with her artistic, public work in a way that reveals a useful mode for her to examine the range of experiences as lesbian, parent, and artist. Thus, these two bodies of work co-exist and inform each other in her oeuvre and in her art with partner Maberry. They have created a kind of sexualized display sometimes inverting heteronormative conventions while other times presenting the family as a single unit, transgressive in its happiness and unity.
\end{abstract}

KEYWORDS lesbians, photography, families, parenting

\section{INTRODUCTION}

In 1996, when I first taught the class "Women in Art," a revisionist approach to the entire history of Western art examining representations, artists, and patrons, I wanted the class to eliminate racial, ethnic, social, and sexual barriers in terms of what the students would be discussing and studying. The class was difficult to teach because enough revisionist scholarship-Whitney Chadwick, Norma Broude, and Mary Garrard wrote the textbooks I used-existed to make the topic available for discussion and analysis, but not enough to show the students a range of artists. Third-wave feminism was just gathering steam by the mid-1990s and the great numbers of lesbian artists who would soon burst on the scene or start getting

I am grateful to the artists for their support of this project and to Margo Thompson for her editorial guidance.

Address correspondence to Anne Swartz, Department of Art History, Savannah College of Art and Design, Post Office Box 3146, Savannah, GA 31402-3146. E-mail: aswartz@scad.edu 
recognition had not yet been the subject of broad analysis. So much more feminist scholarship needed (and needs) to be done that I easily became overwhelmed when I took even a small step out of the canonical view of feminist art history. Now, even as feminist art is in a happy, heady place, the subject of large-scale museum exhibitions like "WACK: Art and the Feminist Revolution," "Global Feminisms," and the installation of Judy Chicago's Dinner Party in the Elizabeth A. Sackler Center for Feminist Art at the Brooklyn Museum of Art, not to mention the many gallery exhibitions and articles and books, the feminist curatorial, critical, and art historical Zeitgeist still perpetuates a limited view of who's in and who's out, as well as what can be looked at for serious discussion. When I was invited to suggest a contribution for this special issue on lesbian art and artists, I wanted to look at an artist whose lesbianism figured prominently in her work and examine an artist who complicated some approach to the way we think about what art is. Cheri Gaulke came to mind almost immediately because of the ways she has combined public and private imagery in her art, which has not been fully examined even as it includes significant images of the lesbian family.

Gaulke is an esteemed feminist artist who creates art and visual culture in all areas of her life, including the personal domain in collaboration with Sue Maberry and their teenage twin daughters Xochi and Marka. This article will focus on the ephemeral family newsletters, cards, and photographs Gaulke and Maberry have created to image their lesbian family in a joyful and sustaining way. ${ }^{1}$ This kind of scholarly intervention is possible because of the way that Gaulke, in particular, lives as an extrovert and uses art as a way to examine her life and give it meaning. She has intertwined her domestic, private imagery and narrative with her artistic, public work in a way that reveals a useful mode for her to examine the full range of her experience as lesbian, parent, and artist. Thus, these two bodies of work co-exist and inform each other in her oeuvre and in her work with Maberry. They have created a kind of sexualized display sometimes inverting heteronormative conventions while other times presenting the family as a single unit, transgressive in its happiness and unity.

The idea of a lesbian family as a visible part of culture emerged as a late twentieth-century conception. The visual culture and meta-narrative structure of the lesbian family is, therefore, still being invented. What makes the Gaulke/Maberry images unique is that Gaulke, who has supposedly turned away from performance art to focus on public art, is, I will argue here, channeling her creative energies into the crafting of a collaborative body of work visualizing a homonormative structure of her family. This essay will add visibility for lesbian families by showcasing how feminist art can generate community and expand contact with heteronormative viewers and participants, as one example of the expansion. Before proceeding, it is essential to point out the importance of Gaulke and Maberry's social and economic class as an aspect of their capacity to provide a stable, prosperous, 
thriving, professional, middle-class home to their children and that same-sex marriage provides stability to children (Carlson and Corcoran, 779; Meezan and Rauch).

\section{CREATING VISUAL IMAGES OF THE LESBIAN FAMILY}

Conventional family portraits and newsletters function differently in their hands as conceptual artworks, as Gaulke and Maberry have injected their family life with the feminist art community and collaboration they learned at the Woman's Building. Interestingly, Gaulke and Maberry have made works dedicated to their lives as lesbian partners and the visual image of the lesbian family, but it is their visual documentation of their family, intended for private purposes, that is truly transformative and, ultimately, activist because they assert the existence of the identity of a lesbian family (Grover, 197). In making a family portrait at a department store, Gaulke noted that the photographer had understood the four were a family, but had thought Maberry was the grandmother and Gaulke the mother. Gaulke remarked about the experience: "On some deeper level, they got that we are family. They just don't have enough public images to name what they perceive" (Gaulke and Maberry 2005, 7).

\section{INITIAL CONTACT AND PERSONAL AND ARTISTIC EVOLUTION}

Gaulke and Maberry evolved as artists in collaboration and as a couple, while also developing individual professional lives. Gaulke became interested in performance art in the summer of 1974 (as a participant in Richard Demarco's Edinburgh Arts where she worked with British performance artists Jackie Lansley and Sally Potter). Gaulke arrived at the Woman's Building in 1975 from the Minneapolis College of Art and Design, radicalized but not yet out as a lesbian. The Woman's Building had been founded in November 1973 by visual artist Judy Chicago, graphic designer Sheila Levrant de Bretteville, and art historian Arlene Raven, evolving out of the Feminist Studio Workshop, the first independent school for women artists, which they had opened earlier that year. Raven defined its mission as the site for a feminist art that "raises consciousness, invites dialogue, and transforms culture" (Wolverton 2002, xiii). Maberry arrived in 1977, two years after Gaulke. In 1979, they both participated in "An Oral Herstory of Lesbianism," a collaborative project of thirteen participants including director Terry Wolverton at the Woman's Building, a landmark performance art work in which each woman presented her experiences as a lesbian. Gaulke was not out during the workshopping process, but was by the time the show opened. As a result, there was much drama surrounding her participation in the performance, as she was relying 
on a definition of a woman-identified woman as her definition of lesbianism, which has parallels in poet Adrienne Rich's definition of lesbianism (Rich, 9; Gaulke 1992/2007, 91). The Woman's Building existed until 1991 and they continued participating in its activities until that time. They are now involved in an extended study of it, supported by a grant from the Getty Foundation.

Gaulke and Maberry became a couple in 1979, had a commitment ceremony in 1986, became parents in 1994, confirmed their domestic partnership in 2005, and married in 2008. Gaulke received great attention in the art world for her performance work, with her piece This Is My Body of 1982-83 receiving notice and critical consideration. In that work, she made a feminist reinterpretation of the Christian Passion, lustily eating an apple in a portrayal of Eve and later being suspended on a cross as Christ. By placing her body within projected images, she reclaimed and reconfigured the artist's identity as distinct from the Judeo-Christian tradition of defining the female body (Meskimmon, 56). In addition to Gaulke's solo work, her artistic collaborations with Maberry (among other artists) continued. In 1981, they produced a series of three letterpress postcards of "Sheela-na-gigs," depictions of pagan goddesses carved in stone displaying their vulvas on Medieval Christian churches. Also that year, they participated in creating Sisters Of Survival (S.O.S.), a collaborative group focusing on anti-nuclear issues who wore nun's habits in the spectrum of the rainbow and presented their anti-nuclear performances; other participants included Jerri Allyn, Nancy Angelo, and Anne Gauldin. Gaulke devoted herself to performance art from 1974-1992. ${ }^{2}$ During the 1990s, Gaulke and Maberry collaborated on several video projects. By the mid-1980s, though, Maberry had turned her attentions to becoming a librarian and university administrator.

\section{BECOMING PARENTS AND CRAFTING A FIERCE COMMUNITY AROUND THE CHILDREN}

The two artists chose to become parents and proceeded methodically and carefully to realize their desire to have a family. Initially, Maberry expressed her interest in having a child to Gaulke, suggesting they adopt. Gaulke balked, fearing motherhood would derail her professionally. Rather than adopting, Gaulke wanted to have a pregnancy: "I thought, 'Well, if we're going to do this, I'd like to do the whole thing.' I had dealt with the body a lot as the content of my work, so I had been intrigued with the experience of being pregnant and giving birth" (Mavor, 190). Eventually, she was persuaded that Maberry would manage the child once it arrived. Home-based insemination led to fertility medications and resulted in a twin pregnancy. Gaulke was terrified that becoming the mother of twins would absolutely halt her career. 
Estranged from their families of origin, Gaulke and Maberry created a chosen family to surround their children. As occurs in many families, children eventually brought the artists together with their families of origin. Gaulke and Maberry's 1986 commitment ceremony, initiated largely to affirm that they intended to have a child, took place in Sue's parents backyard. After the children were born, Gaulke commented that her parents could not stand the idea of not knowing their granddaughters and, thus, became involved in the children's lives, even as they disdained the couple's lesbianism. Eventually, both sets of grandparents have become accepting of Gaulke and Maberry as a couple, although the road to acknowledgment from Gaulke's family was not an easy one for the artists (Gaulke, 2009d).

Simultaneously, or shortly after Gaulke (and Maberry) accepted the idea of becoming parents of twins, Maberry read an article on human development by psychologist Peter L. Benson, which cited a figure of four to six adults in addition to parents actively involved in a child's life would prevent juvenile delinquency. So, the artists gathered together a group of "aunties," women who would act as a surrogate extended family and form a community around the children in the absence of the biological extended family. Artist Jerri Allyn is one of the members of that informal collective. She remarked that Gaulke and Maberry's children were "birthed in community," describing the artistic survival skills taught at the Woman's Building in Los Angeles, where Allyn, Gaulke, and Maberry were all students in the mid1970s, translated into life skills (Allyn).

Some of the women in the "group" were artists and some were artists who were members of Gaulke and Maberry's Wicca coven or circle, Nemesis. Paganism was an outgrowth of their experiences studying feminine power and experiences at the Woman's Building, where both became interested in pagan practices and Goddess worship, which has formed a central part of their family's life. Eventually, Gaulke and Maberry, seeking more formal family activities such as an institutional church with a building and families with children of all ages would provide, became involved in a Unitarian Universalist church congregation when the children were two. In order to communicate the experience of becoming parents and then about life as a family, Gaulke and Maberry began making visual records of their life together.

\section{PRIVATE AND PUBLIC}

Gaulke's accidental project (she was surprised when I told her I wanted to focus on the visual culture of her family that she was creating) has an important goal; that is, to make the lesbian family, theirs in particular, visible and create a record of their life together. I am initiating a useful feminist analytic method here by dissolving the traditional boundaries between public

and private art because I value and read these texts as a significant part of 
Gaulke's recent work. Gaulke has received considerable art world attention as evidenced by the numerous articles, reviews, and citations of her art by significant critics and historians; however, the omission of her work from such exhibitions as "WACK: Art and the Feminist Revolution"3 demonstrates that artists come to critical attention, but don't always receive sustained interest simply as a result of the vagaries of critical and curatorial definitions. The situation for women artists - which is even more pronounced for lesbian artists-is one of invisibility, even in arenas devoted to the kind of work they make or made. I became aware of Gaulke's work through my friendship with and study of the writings of the late art critic Arlene Raven, who had been one of the artist's teachers. Raven stressed to me the value of looking at artists like Gaulke who made important work but simply had not received the kind of attention the work deserved because of the curatorial and critical Zeitgeist. Raven impressed upon me, as has artist/critic Joanna Frueh, the importance of looking beyond the canon. Gaulke's visual and textual framing of her family stood out to me as I learned about how she and Maberry had created their family and community from their coupling, more vibrant and joyful than any family I know with engagement that prompted me to look more closely at the range of materials produced in the name of "keeping everyone up with the family's news" where I discovered a sensitivity that mirrored the more publically oriented art (Swartz). As an activist gesture, I bring it to your attention. A note about context here: these privately crafted works co-mingle with the publically defined ones to create richer imagery and strengthen the narrative of the more public works.

Such a project becomes extremely important when one considers the history of representations of lesbians. The London-based Lesbian History Group has noted the relative concealment of lesbians in almost categorical terms: "Lesbians do not usually leave records of their lives. Those who do may not include any details which would identify them as unmistakably lesbians" (Lesbian History Group, 3). Additionally, that they are selfrepresenting is also important since the representations of lesbians that exist are sometimes conceived by heterosexuals to serve heterosexual desires (Lesbian History Group, 3). Although the indicators for lesbianism in Gaulke and Maberry's images and text are evident, I will highlight them in detail here. The absence of unity in representation produces an anxious state for lesbian artists who have numerous options available, while simultaneously creating the potential for choice in how they will self-represent. Writer and artist Harmony Hammond has noted that assimilationist images of lesbian families are the most problematic, as they "rattle the very foundations of that mythic institution [-] the American family" (Hammond, 156). She used the portraits of pregnant Gaulke and Maberry as a couple by Laura Aguilar and their artworks on the lesbian family as evidence of her point here.

Gaulke and Maberry give extensive details about themselves, their children, and their family life together and separately as individuals. There is 
ever-present joy in these texts as records, which were intended as evidence of the family's life, its happiness, and the trials they experienced. Additionally, they document its very existence, using the power of what is otherwise potentially banal correspondence to make it into something activist. So, in this manner, objects made for private circulation become part of a greater project of these two artists in documenting their experience.

To look at privately crafted and circulated correspondence, and to accept the broader definition of them as art, is to understand how they fluidly functioned for the artists; much of the text and imagery in the newsletters and cards filtered into and informed their artists' books and installations of the 1990s and 2000s. The artists have lived an extroverted life and regard their life (in almost all ways) as part of their art.

Together Gaulke and Maberry have created several art works that deal directly with the structure of the lesbian family and its representation. They produced the installation Thicker Than Blood: Portrait of Our Lesbian Family in 1992 for "Communitas: The Feminist Art of Community Building," curated by Betty Ann Brown and Elizabeth Say at California State UniversityNorthridge. Significantly, this project was the first time Gaulke was out in her work in the mainstream art world, beyond her experiences in the performance art realm and the feminist art world (Gaulke, 2009a). Gaulke described the piece as follows:

It was both an installation and conceptual performance in which we invited our dearest friends to go to Sears, that bastion of American values, and have their portraits taken. We framed the portraits in gold-leaf and included lots of framed snapshots as well. The people included were not all gay (in fact more were probably heterosexual). The idea was contextualizing our family of choice as being "lesbian" instead of the way in which gays and lesbians are seen within the context of heterosexual blood lines. (Gaulke, 2009c)

The artists emblazoned "A Lesbian Family" across the gallery wall, behind the framed portraits, showcasing the community they had crafted as their family unit. These ubiquitous pictures have become the conventional portrayal of the family unit, popularized as a way to document the growth and maturation of a family.

On the subject of the specifics of creating a family, Gaulke and Maberry collaborated on a video project Sea of Time in 1995 that they then examined in an artists' book Offerings at the Crossroads in 2005 (Klein, 13). Sea of Time is a twelve-minute single-channel video combining the narrative about Gaulke and Maberry's effort to become pregnant alongside a vacation to Bali and examining their relationship with significant members of their extended family circle, Roger Workman and his partner Mark Niblock-Smith, who is dying of AIDS. The book included a pouch made from Balinese sarongs 
containing the artists' book, in the style of traditional palm-leaf books. The book begins: "Mark began dying of AIDS long before I began trying to conceive, both of us racing against the inevitability of time." Offerings at the Crossroads is an examination of "the idea of family and queer parenting" (Klein, 13).

Subsequently, they produced Families Next Door (1995), made for the exhibition Community Properties at the Huntington Beach Art Center, which was another work offering new portraiture conventions using Sears portraits. In their statement, they remark, "We are in the midst of a gay baby boom" (Gaulke and Maberry 1995). As an artwork, Marriage Matters (2005) is a significant recounting of many of the key episodes in their life as a couple and family. It was intended as an artwork for an art world audience, while the family newsletters, card, invitations, and programs form a more private kind of documentation. As art historian Catherine Zuromskis points out: "vernacular photography seems, at times, to resist critical intellectual scrutiny entirely" (Zuromskis, 104). Images of the couple combine with photographs of beloved pets, installation shots of art works, a portrait of the newborn twins, and three family portraits. Some of the narrative of this artists' book mirrors or references material used in the family newsletters or cards. The tone here is relentlessly hopeful and expectant. The speaker is Gaulke, who writes on the last page, "Standing on the Side of Love":

I am inspired by the daily lives of other lesbian and gay couples who live in a country that doesn't treat us equally. My deeply optimistic nature makes me believe that people don't really hate us. They just don't know us. (Gaulke and Maberry 2005, 9)

Discussion of connections to community, fears and misconceptions about homosexuality, lesbian families, and marriage, and discussion of their evolution as a family all co-exist in this text. It was shortened and presented as a dramatic reading at the couple's 2008 wedding as "A History of Love."

\section{THE STORY OF THE VISUAL NARRATIVE}

When Gaulke and Maberry decided to expand their family, they turned their attentions to creating a visual and verbal record for their community, specifically their lesbian family. In 1993 at the time of the Winter Solstice, they produced an illustrated two-page newsletter, chronicling their pregnancy, their home life (including consideration of the impact of the new children on their pets), their career developments, updates on their extended family, and the status of their Circle (Figure $1^{4}$ ). They also introduced Gaulkberry, the new last name they were considering for their new family. Gaulkberry ended up not becoming the children's name (that is Maberry-Gaulke), but 
briefly became the title of their newsletter, the Gaulkberry Gazette, from 1995 to 1996. The somewhat unspoken piece of this account is the general absence at this time of Gaulke or Maberry's families of origin in participating in the preparations for the children's births. Gaulke speaks to the fear of

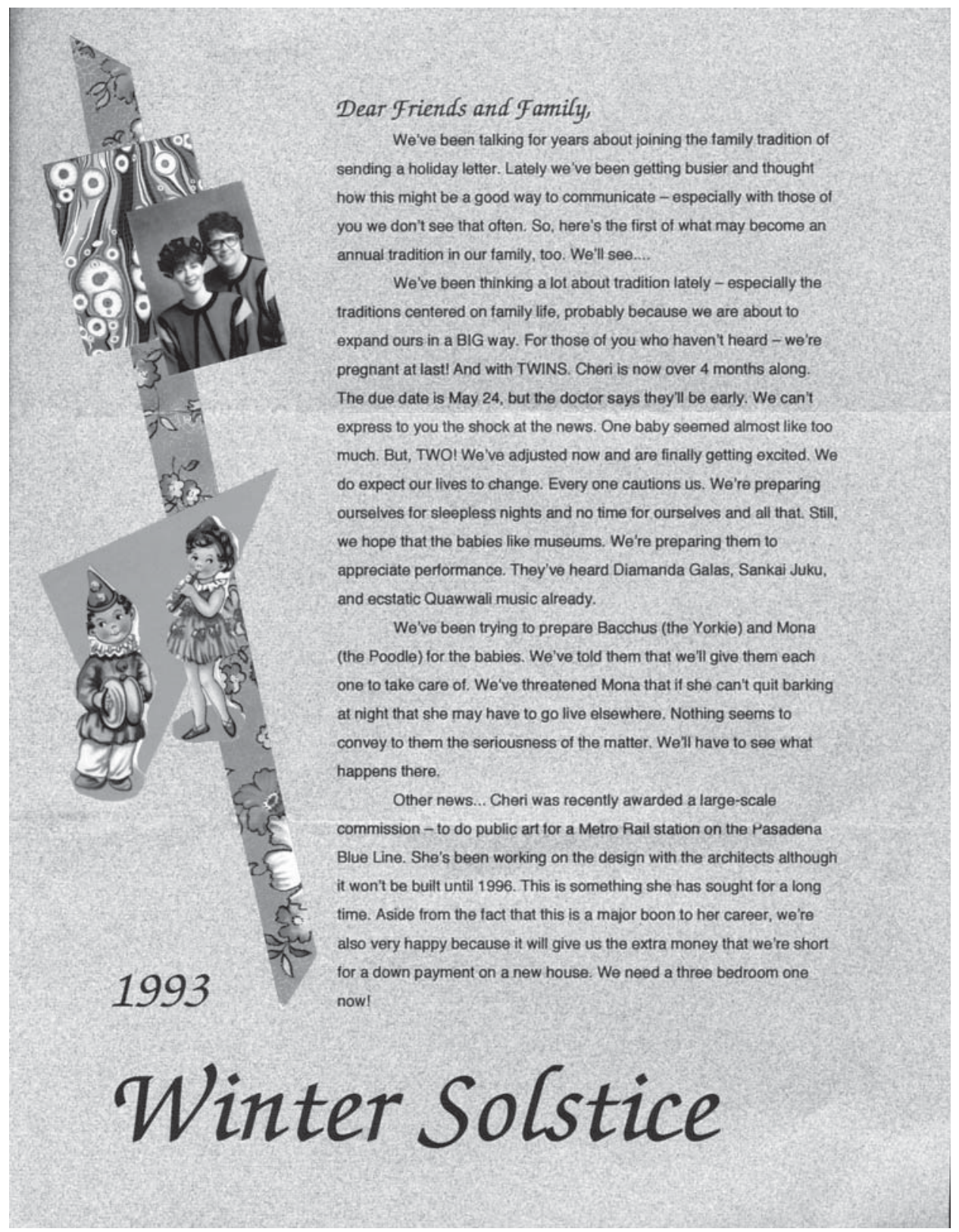

FIGURE 1 Cheri Gaulke and Sue Maberry, Winter Solstice 1993 Newsletter, two pages, 81/2 $\times 11$ inches. (Reprinted with permission.) 


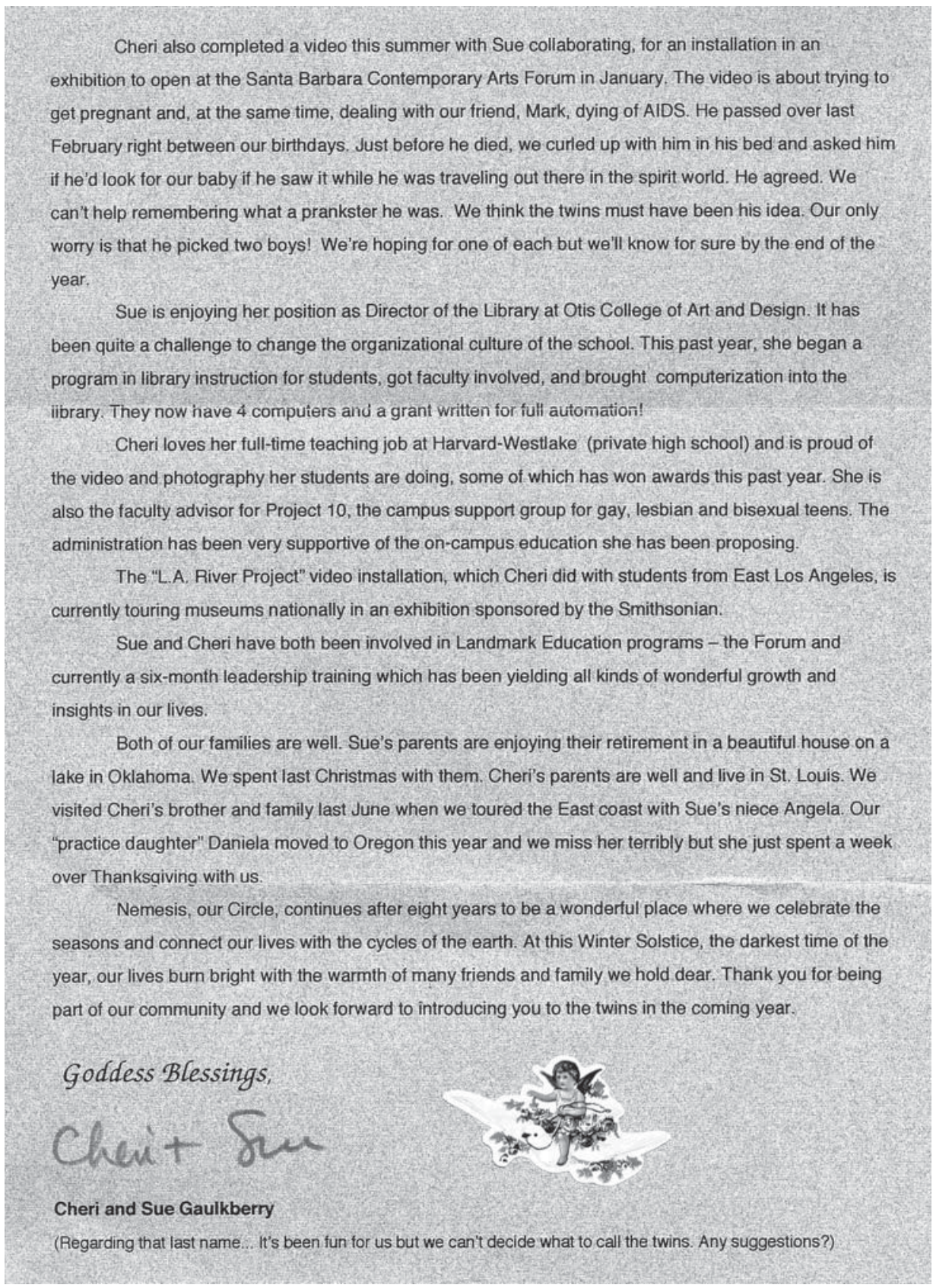

FIGURE 1 (Continued).

grandparent abduction generally, not specifically, and provides the details of the twins' birth, including the decorations and the involvement of members of their Coven in the text of Marriage Matters, the artists' book they created in 2005 (Gaulke and Maberry 2005, 6). By the time the children were nine 
years old, things had shifted considerably in this family, as Maberry's father visited during the summer of 2003 to manage the girls' care in Gaulke's absence while she was traveling to make an artwork.

Gaulke and Maberry were the subject of a pair of collaborative portraits for photographer Laura Aguilar's series Clothed Unclothed from 1990-1994 (Figure 2). For their participation, the artists received prints of the images. The artists were photographed in 1994, as Gaulke is significantly pregnant in the images-taken three weeks before her due date. I am concerned with self-representation of the lesbian family in this discussion and Aguilar's

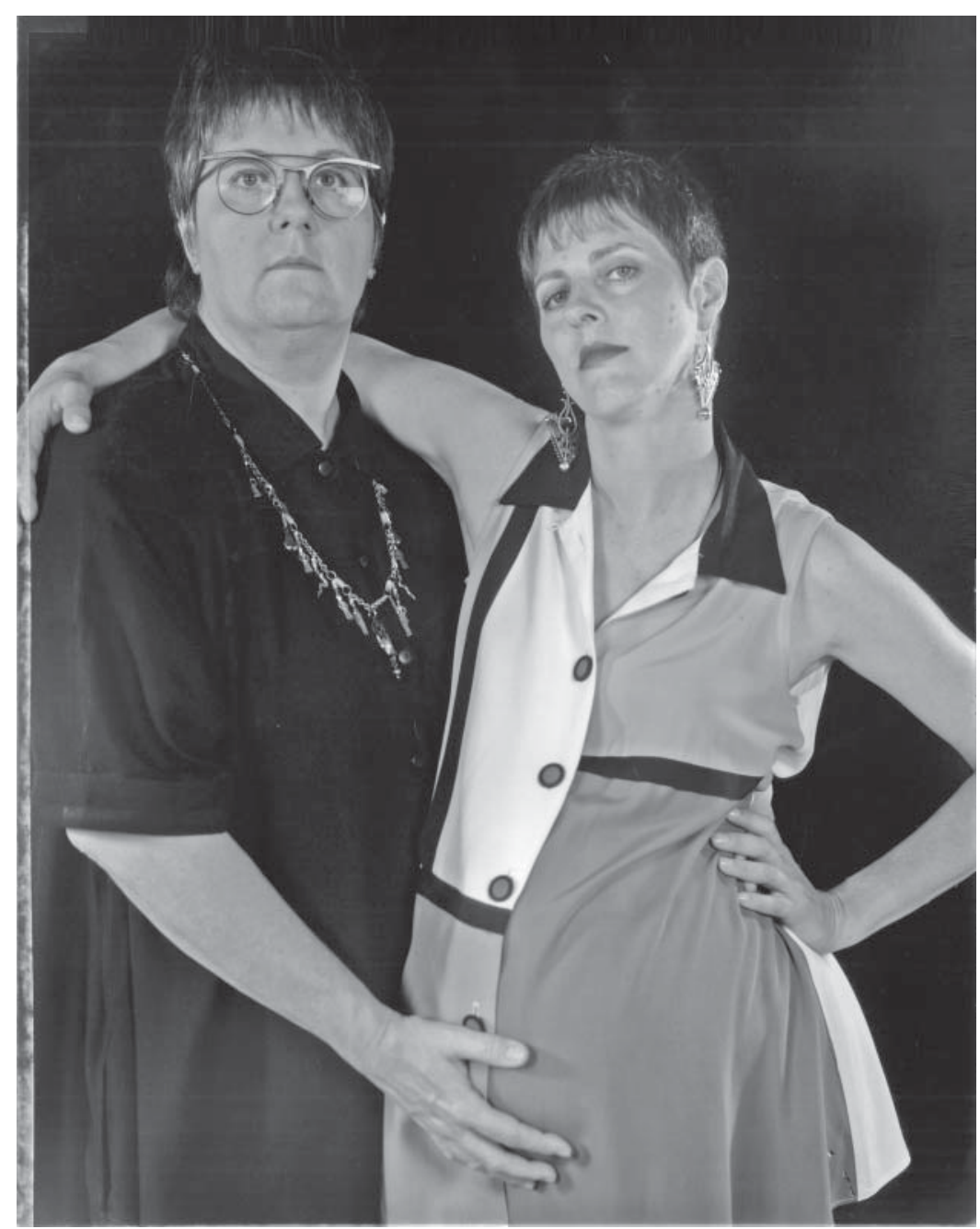

FIGURE 2 Laura Aguilar, Cheri and Sue, 1994, 1994 from Clothed Unclothed series, gelatin silver prints, two images, each image $16 \times 20$ inches, Collection of Cheri Gaulke and Sue Maberry, Los Angeles, CA. (Reprinted with permission.) 


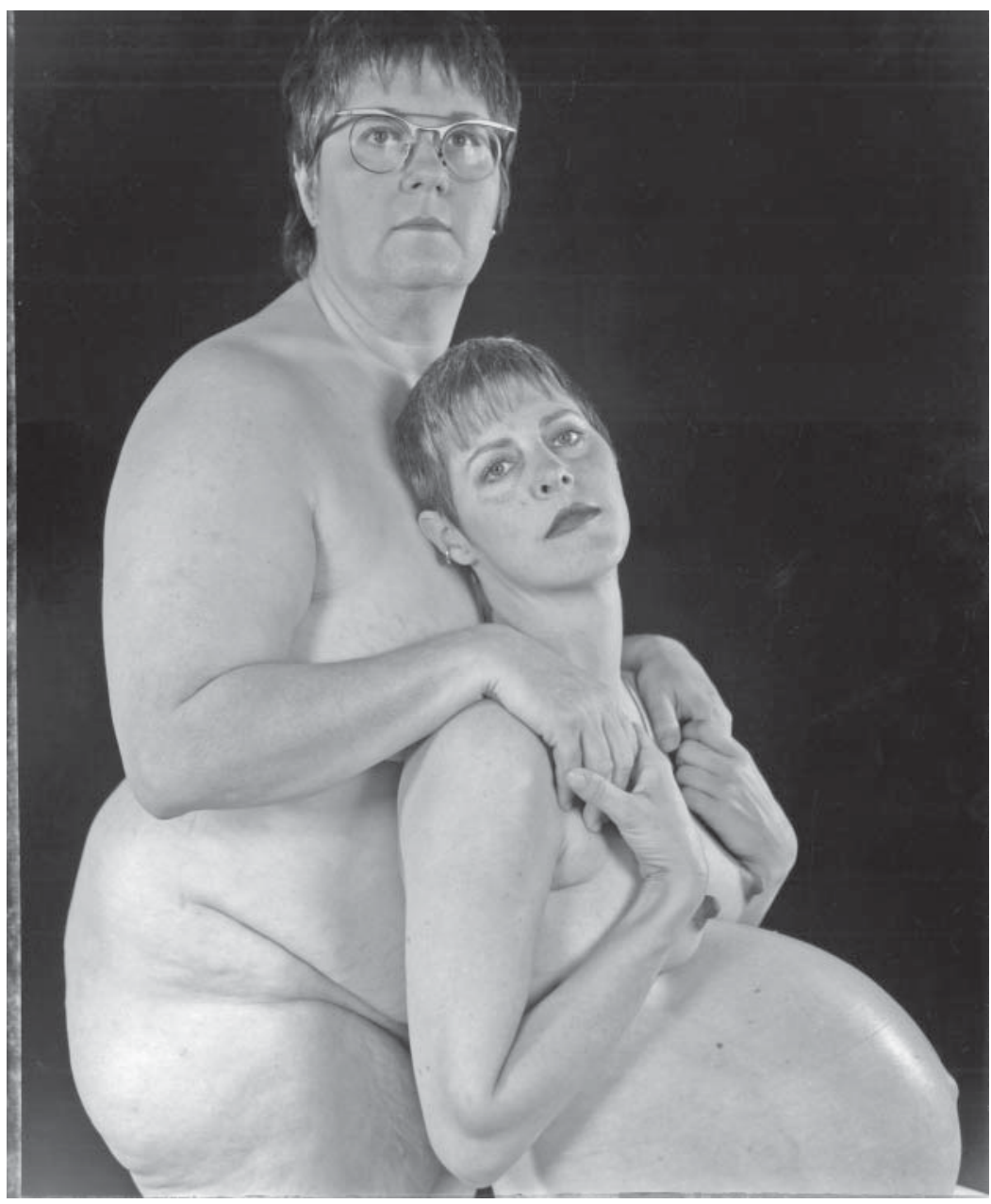

FIGURE 2 (Continued).

approach is cooperative and clearly conveys her subjects' affection for each other. The artist remarked about her collaborative approach:

I work with my subjects directly. I interact with the subjects by using polaroids. ... I use them to shape the final images because I shape the photographs but I work with the subjects to ensure they comment on how they are standing and how they look. I create two final sets of images and ask the subjects to choose which will be the final image. (Aguilar)

This diptych holds a place of prominence in their home because it is displayed over their bed and can be seen from their kitchen (Swartz). These images are intended as a diptych: the left image shows Gaulke, pregnant, and Maberry dressed with her hand on Gaulke's lower abdomen in a position 
which connects Maberry to the pregnancy both visually and symbolically. Maberry's angular glasses remain for both photos and form an interesting contrast in the clothed version to the geometry of Gaulke's maternity wear shirt. Aguilar presents them in an assertive pose, standing adjacent, with Gaulke's arm extending slightly upward over Maberry's shoulder and forming a parenthetical contrast to Maberry's downward sloping arm. The right image shows the very pregnant and naked Gaulke seated covering her breast while holding hands with the also nude Maberry in what art historian Alyce Mahon calls "a lover's embrace" (Mahon, 268). Maberry stands in the dominant location above and behind Gaulke. Both Gaulke and Maberry gaze seriously and directly into the camera lens in these images; the vague and somewhat fierce facial expressions are relieved in the unclothed image by Gaulke's head resting back on Maberry's chest. Aguilar explodes conventions for photographic portraiture in these images of outsiders, including lesbians, gays, and Latinas, among others. That this diptych was a new kind of representation is perhaps best conveyed by the negative reception it received, and the controversy that resulted, when it was published in a University of California-Irvine employee newsletter in advance of an exhibition of Aguilar's photographs (Lord, 3).

The twins arrived on May 21, 1994, surrounded by goddess images pasted all over the labor and delivery room, and a cadre of Gaulke and Maberry's friends in their created family. When the labor turned to an emergency cesarean, they brought along many of their friends, resulting in, perhaps, one of the largest groups in the operating room, to ensure the children were encircled by love. The baby announcement cover (Figure 3) shows the nude Gaulke fully pregnant in a frame, while the interior of the card shows an image of the babies inside the same frame. The babies' names are explained: Xochi, from the Nahuatl-Aztec word for flower, and Marka, named after their friend Mark Niblock-Smith, along with the babies' sizes, weights, and times of birth.

Gaulke and Maberry focused on a naming ceremony two months after the twins' arrival, memorialized by the invitation and the program of the rite (Figures 4 and 5). The Pagan ceremony has resemblances to tribal rituals: the child is presented to the community and blessed when the name is bestowed or confirmed. The invitation gave all invited guests the opportunity to send "words of wisdom" to the children. The invitation makes a play on "coming out" with a cartoon bubble over Xochi announcing "Hey Marka! Our mommies are throwing us a coming out party..."; coming out in this context is the way the children are presented to their community using the verbiage of homosexual emancipation.

The coincidence of a lesbian couple having twin girls bespeaks the narcissism of homosexuality, which is a theme Gaulke and Maberry play on in the twins' first birthday invitation. A teasing and light-hearted homoerotic theme is apparent here (Figure 6) with the cartoon bubble, again over Xochi, 


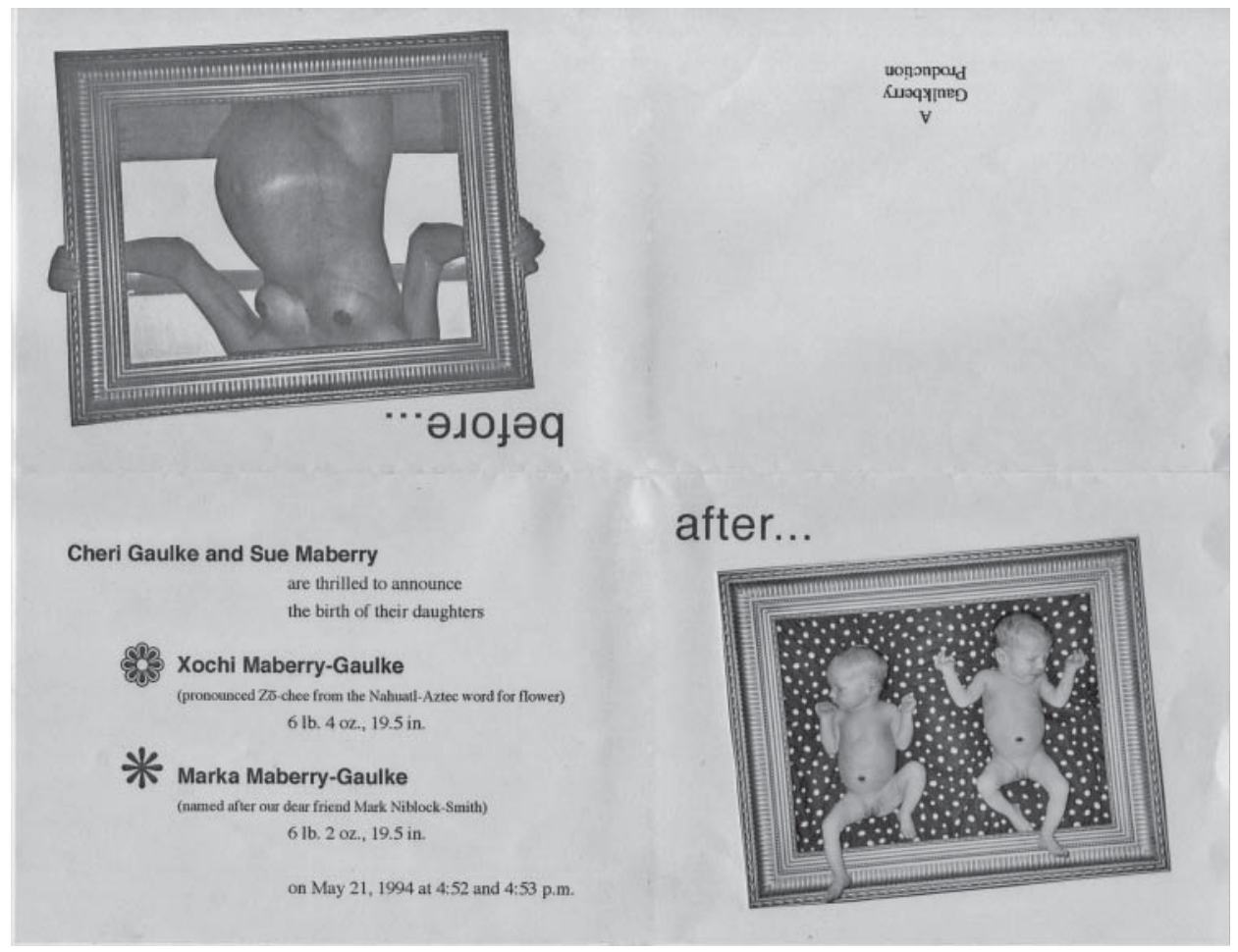

FIGURE 3 Cheri Gaulke and Sue Maberry, Baby Announcement, 1994, single-sided document, different folding convention, photostatic copy, $8 \frac{1}{2} \times 11$ inches. (Reprinted with permission.)

announcing "Bring on the dancing girls!" It invites guests to enjoy such activities as "[watching] babies smear cake all over their faces." More than seventy-five people attended their party (Mavor, 185-86). These early documents were followed by three Gaulkberry Gazettes, dated Summer 1995, Winter 1995, and July 1996 (Figures 7, 8, 9). They recount the children's development, maturity, and growth, as well as Gaulke and Maberry's progress as parents, as professionals, and as women. Maberry's legal adoption of the children is mentioned in the Winter 1995 issue alongside many other events, although this occurrence was significant. It heralded the sanctioning by the state of the family as a unit. And it meant that both mothers were parents equally, thus diminishing any potential concerns about familial dissatisfaction with the two women raising the children.

In 1996, perhaps at the time of envisioning a fantasy family crest for Maberry's Oklahoma-based parents, Gaulke and Maberry created a Gaulkberry Family Crest (Figure 10). Gaulke explains its symbolism: "The four snakes represent our four family members and the four quadrants represent feminist community, artmaking, home, nature/feminist pagan spirituality" (Gaulke 2009b). Snakes have a long history of signifying matrilineal 


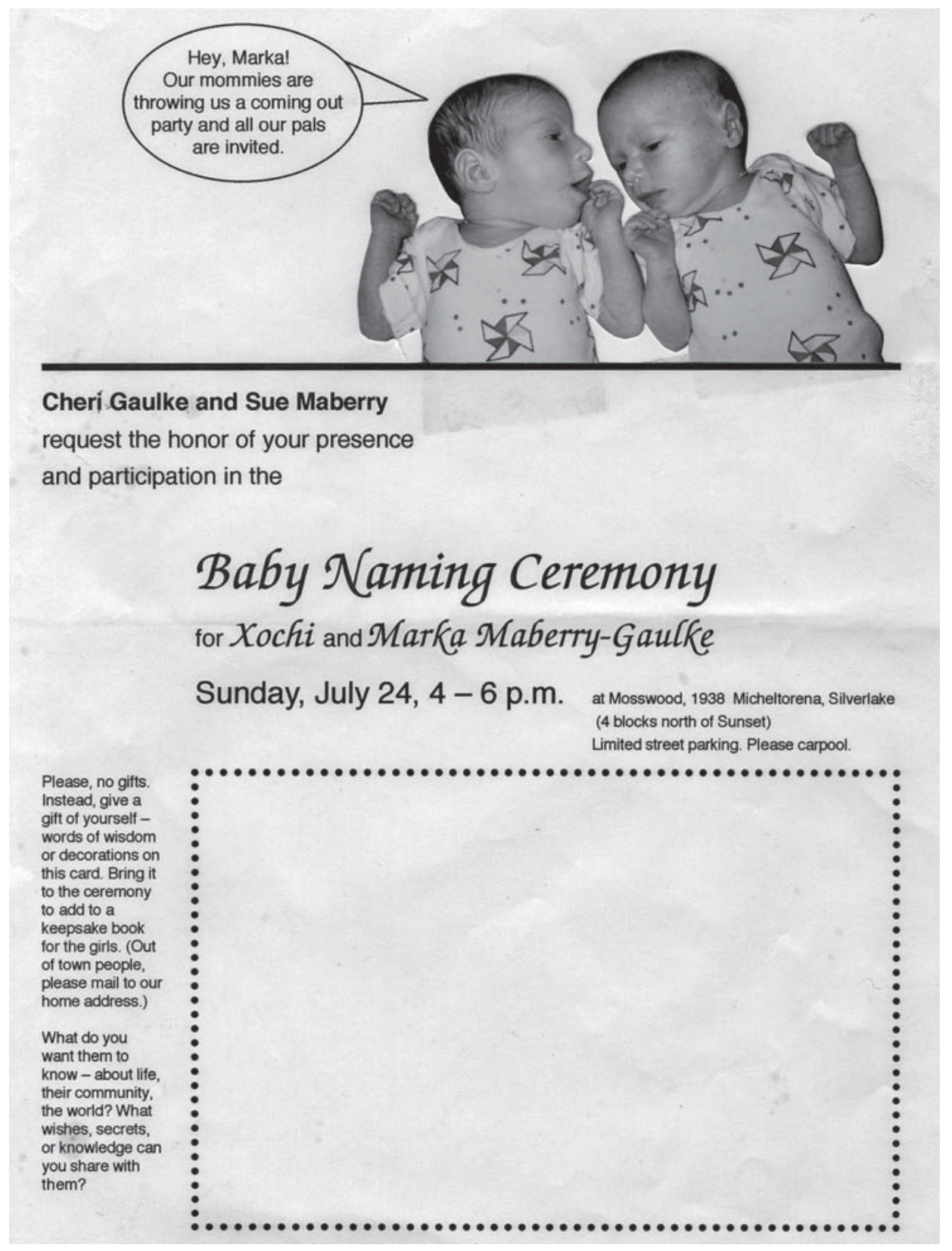

FIGURE 4 Cheri Gaulke and Sue Maberry, Invitation to Baby Naming Ceremony, 1994, singlesided document with participatory section, photostatic copy, $8 \frac{1}{2} \times 11$ inches. (Reprinted with permission.)

power, as evidenced by the snake goddesses from ancient Minoan art. The persistence of Pagan spirituality as a powerful creative force in the MaberryGaulke family life is reiterated as well by the goddess figure adjacent to the spiral, a yonic symbol for generative powers and natural energy forces. 


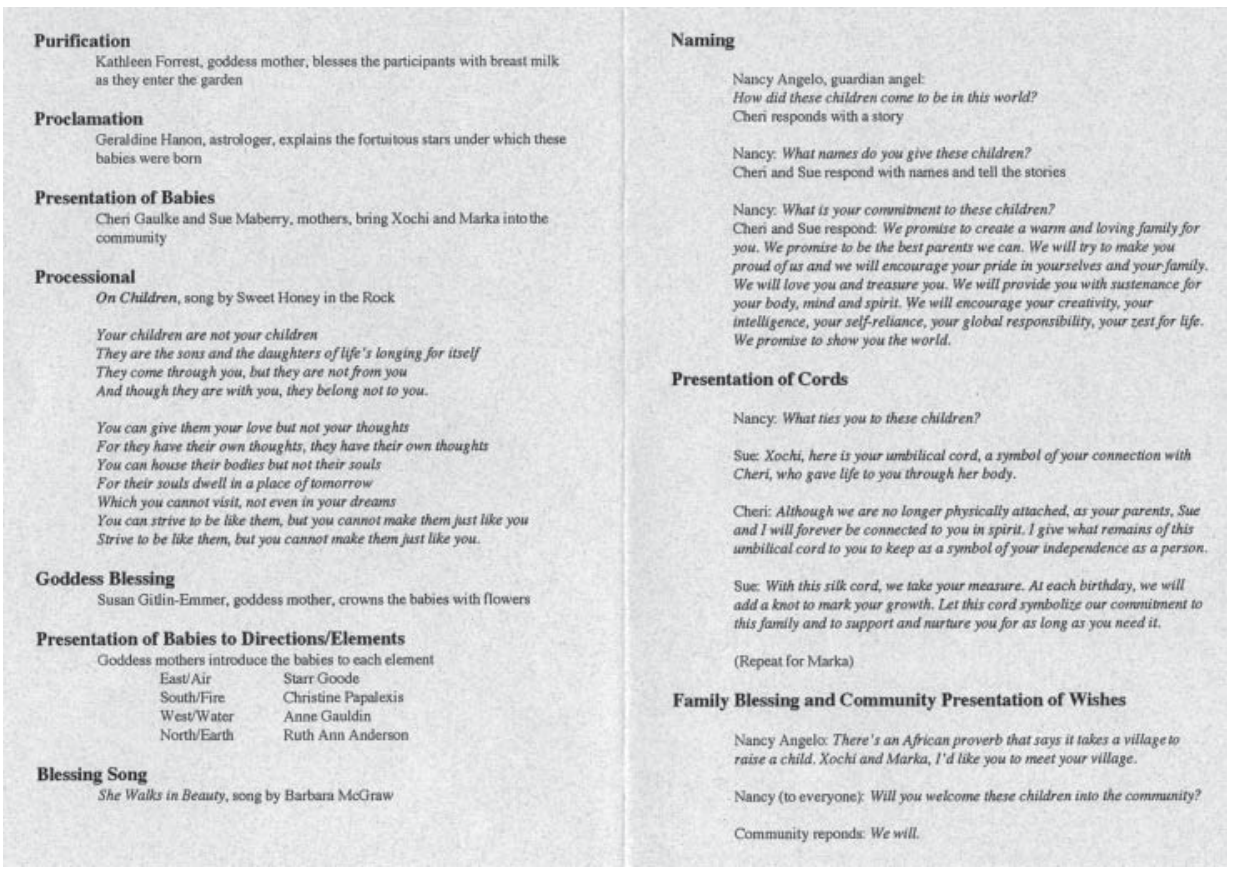

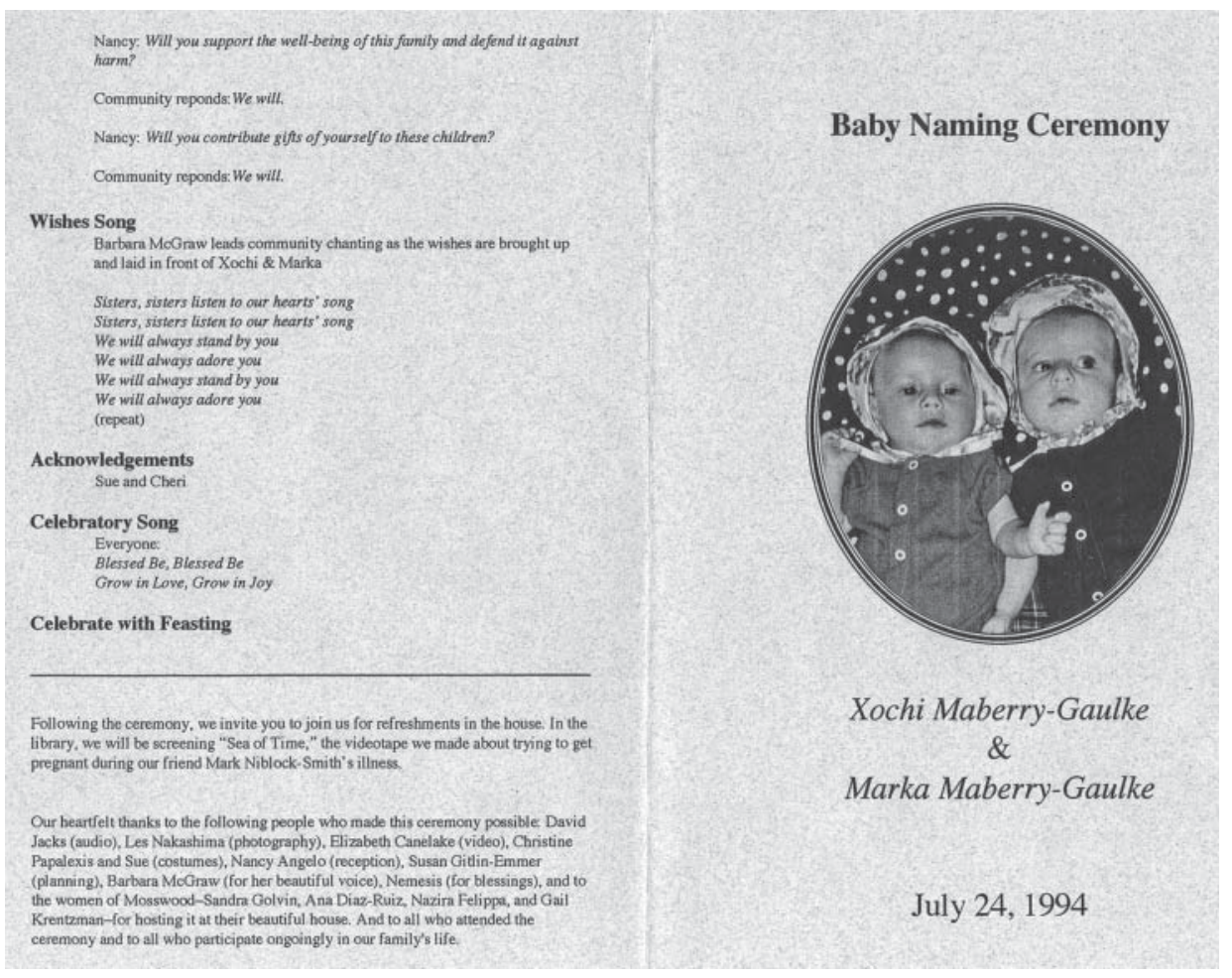

FIGURE 5 Cheri Gaulke and Sue Maberry, Program for Baby Naming Ceremony, 1994, double-sided document, photostatic copy, $8 \frac{1}{2} \times 11$ inches. (Reprinted with permission.) 


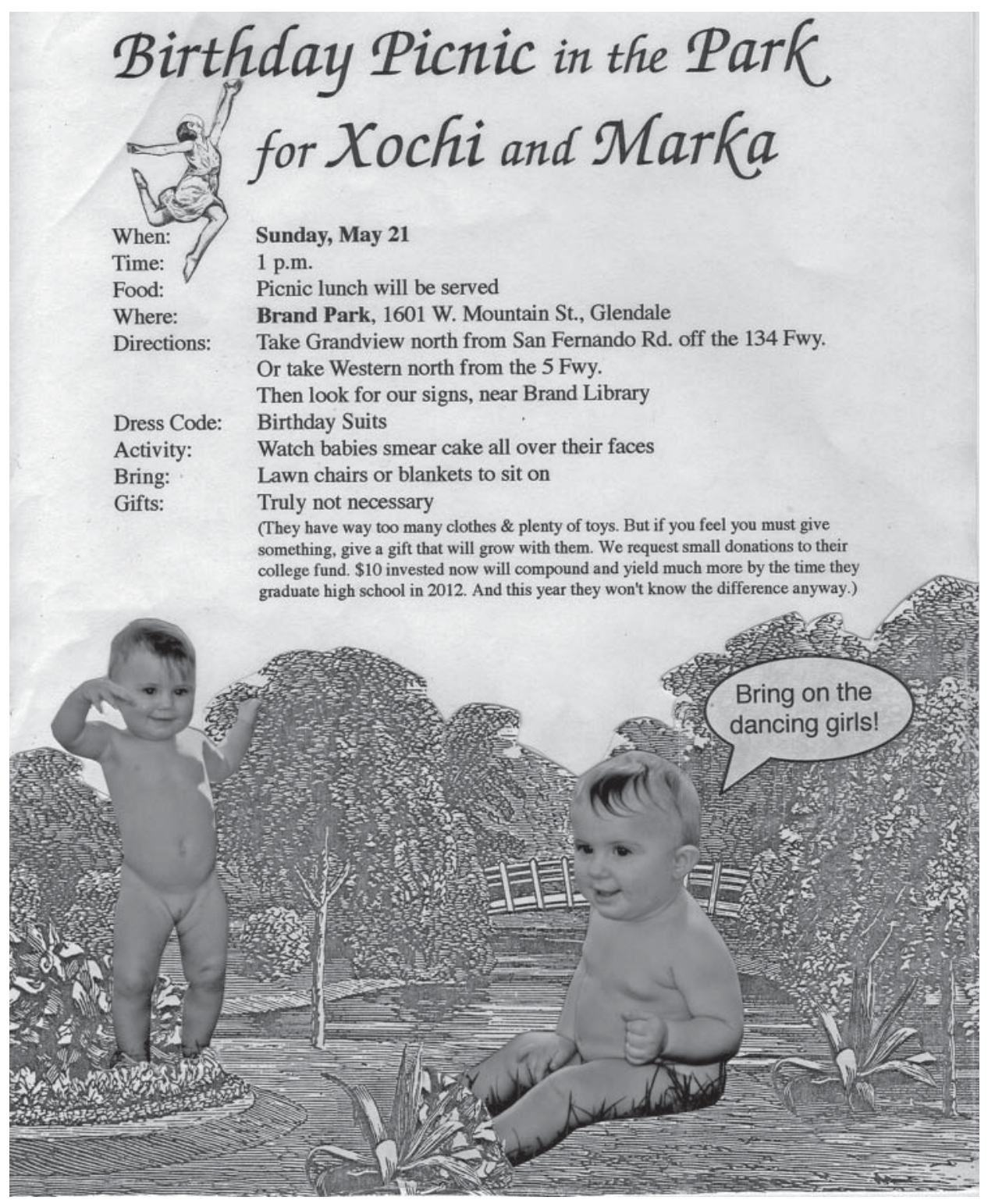

FIGURE 6 Cheri Gaulke and Sue Maberry, Invitation to Twins' First Birthday, 1995, singlesided document, photostatic copy, $8 \frac{1}{2} \times 11$ inches. (Reprinted with permission.)

\section{THE PROJECT EVOLVES}

The production of these documents changed as the girls grew up. The hectic pace of life meant that no documents (save an annual themed birthday party, accompanied by an invitation like the one from the twins' first birthday) were produced from 1997-2002. Then, in 2003, the children had grown 
up and the family had found a routine. Attention could return to documenting and reflecting on the family. At this point, the imagery shifted, the designs improved, and the presentation became more professional. Gay marriage and lesbian families remained contested. However, by this time,

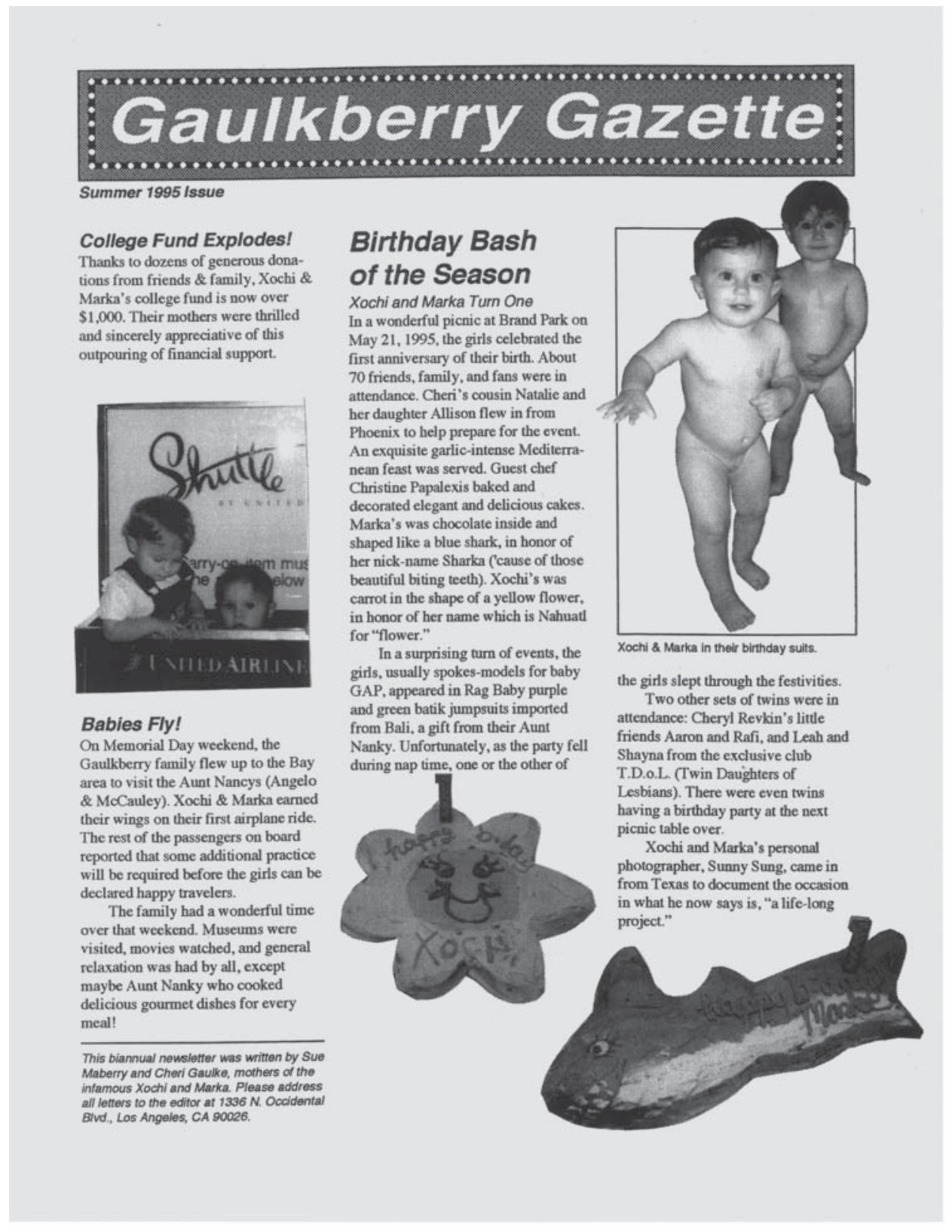

FIGURE 7 Cheri Gaulke and Sue Maberry, Gaulkberry Gazette, family newsletter, Summer 1995, double-sided document, photostatic copy, $8 \frac{1}{2} \times 11$ inches. (Reprinted with permission.) 


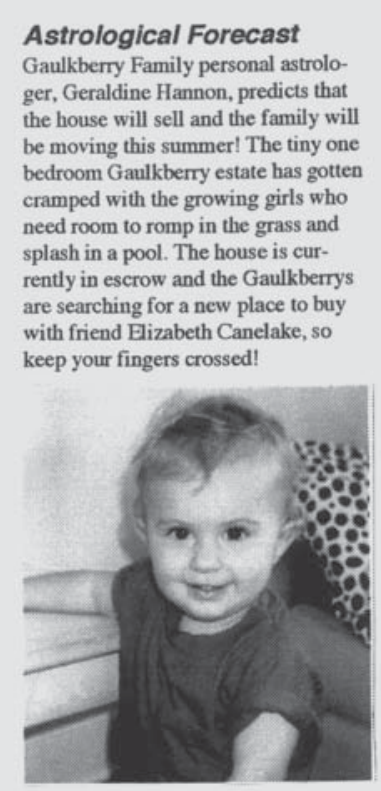

Babies to Appear in Court Not to be outdone by OJ. Simpson's fame, Xochi and Marka have demanded their own special courtroom event. On July 6 at 10:30 a.m., they will appear with their mothers and their lawyer, Diane Goodman, to make legal Sue's mother status. Right after their birth, Sue filed a petition to adopt. After this hearing, Sue's name will appear on their birth certificate. All fans are invited to share in this celebration and join the Gaulkberry family for lunch afterwards. Call for details. Marsha Clark was unavailable for comment.

\section{Walk Don't Run}

Xochi was determined to walk and methodically approached the task. She gradually mastered each step in the process until she walked precariously before she was 11 months old. Marka was happy with her perfected "turbo crawl" until the week before her birthday. At that point she simply got up and walked. Thank you very much.

\section{Grandparents Update} Cheri's parents made a surprise visit recently when they were in town on other business. Marka thought her Grandpa was pretty funny wearing her Mickey Mouse hat and Xochi loved playing hide and seek with her Grandma.

The Gaulkberrys fly to Oklahoma on June 18 to visit Sue's parents. They're looking forward to 10 days in a big comfortable house on the lake, with tree-filled yard, four Yorkies, and one speedboat.

\section{Words Galore}

The mothers are sure they have two genius babies. Already Xochi \& Marka have an incredible vocabulary. Interestingly, most of their words start with "b." They say, baby, bottle, byebye, Bacchus, bite, ball, book, booby. boom, boo, belly, bear, and banana. Plus mama, Mona, and a few others. Such brilliance!

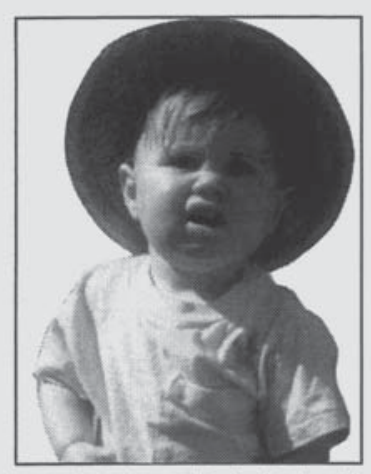

Ladies \& Gentiemen, Elvis has left the cribl

\section{Dr. Declares Drama Queen!} In her one year visit to the pediatrician, Marka's symptoms were diagnosed "Drama Queen." Dr. Cheryl Wickham began to note a pattern in behavior as her mothers recounted various incidents such as fingers down her throat, biting her sister, head banging, and projectile vomiting in the car. Doctor's prescription was, "Ignore this behavior."

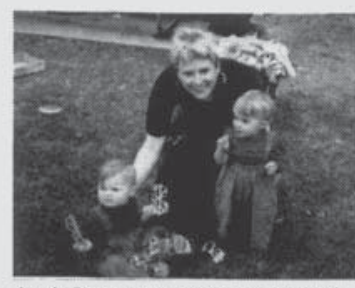

Auntie Starr, the pre-eminent "baby hog"

$X$ \& $M$ Facts

Favorite game: Peek-a-boo. Favorite books: Goodnight Moon, Bye-Bye Babar \& Everyone Poops.

Favorite foods: Bananas, pasta, carrots, goldfish crackers.

Favorite clothes: Birthday Suits

Favorite nicknames for Xochi:

Xochininni, Mochie, Mochianna,

Mochinni, Moonchkin.

Favorite Marka nicknames: Sharka,

Markie, Moonchkata, Pie, Elvis.

Favorite Aunts: "No comment."

Favorite Toys: old photos, any detritus off the floor, jewelry.

Favorite activities: Going for walks in

the backpacks. Playing outside.

Pulling things out of trash cans.

Re-arranging all chairs in the house. Climbing up the slides in the park.

\section{Angel Watches Over Girls} The girls spend their days in the capable hands of Angelica, their babysitter. She offers them a routine much more predictable than their mothers (for which they are grateful). They nap, eat, drink bottles, and play in the yard. From Angelica's front porch, they observe the neighborhood, waving to birds, helicopters, gatos (cats), and a steady stream of children, teenagers and adults. They love Angelica and look forward to their time with her. She loves them and claims "they never cry" because she meets their needs before they even know they have them. The mothers were lucky to find such a good caregiver (thanks to the best referral service around, Cheryl Revkin).

$$
\text { Although Cheri will be out of }
$$
school for the summer, the girls will continue to go to Angelica's so Cheri can devote full-time to her art.

FIGURE 7 (Continued).

the Gaulke/Maberry family had settled into a more confident place perhaps because of their more conventional involvement in the Unitarian Church as a balance for the family's more alternative Pagan practices, reconnection with Gaulke and Maberry's families of origin since the grandparents in particular did not want to miss out on their grandchildren's evolution, and the 
parents' assurance and certainty with their capabilities in creating a loving environment to raise their children (Gaulke and Maberry 2005, 8; Allyn).

The newsletters became briefer in recounting the family's experiences over the course of a year and the graphics became more vivid, while the

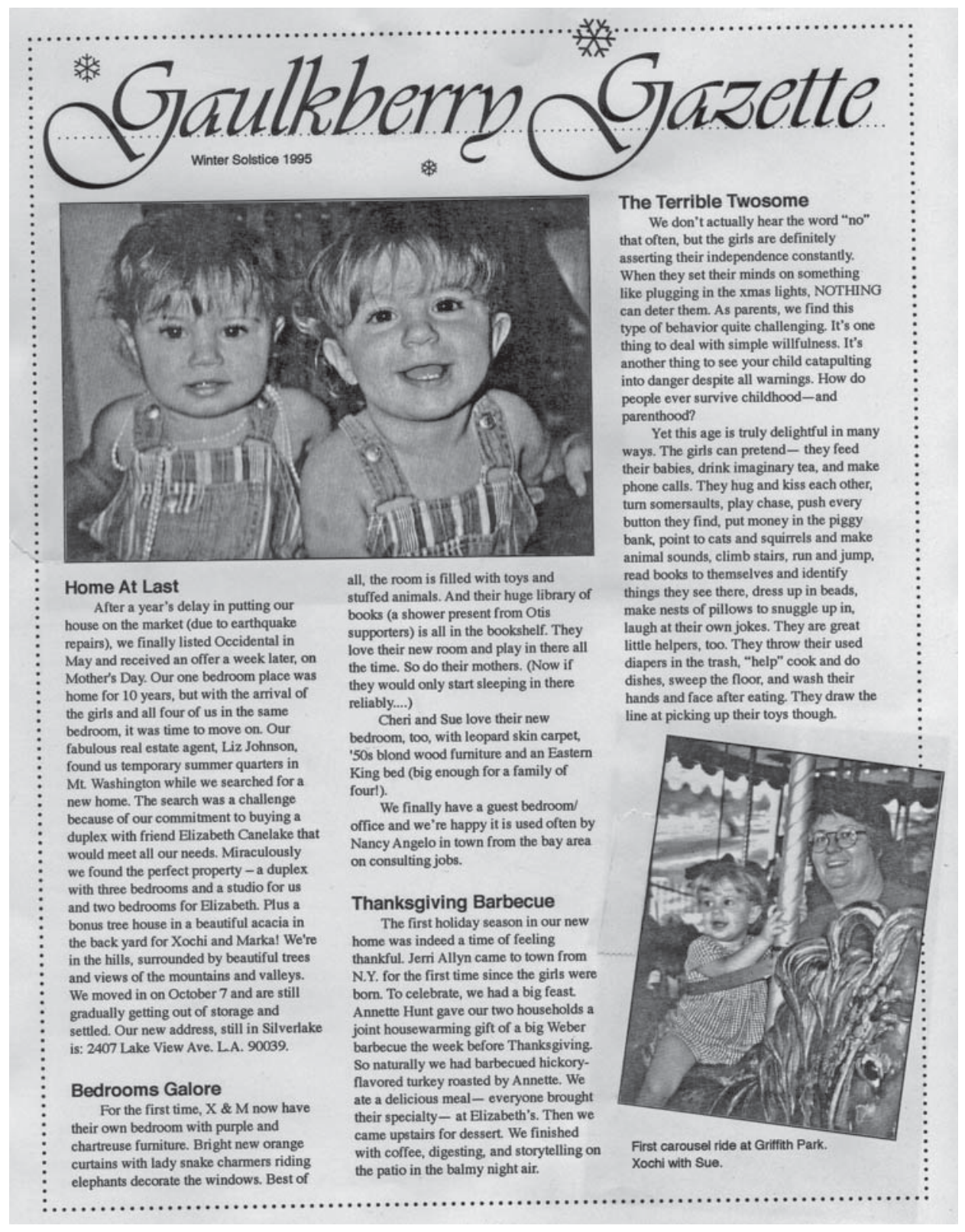

FIGURE 8 Cheri Gaulke and Sue Maberry, Gaulkberry Gazette, family newsletter, Winter Solstice 1995, double-sided document, photostatic copy, $8 \frac{1}{2} \times 11$ inches. (Reprinted with permission.) 


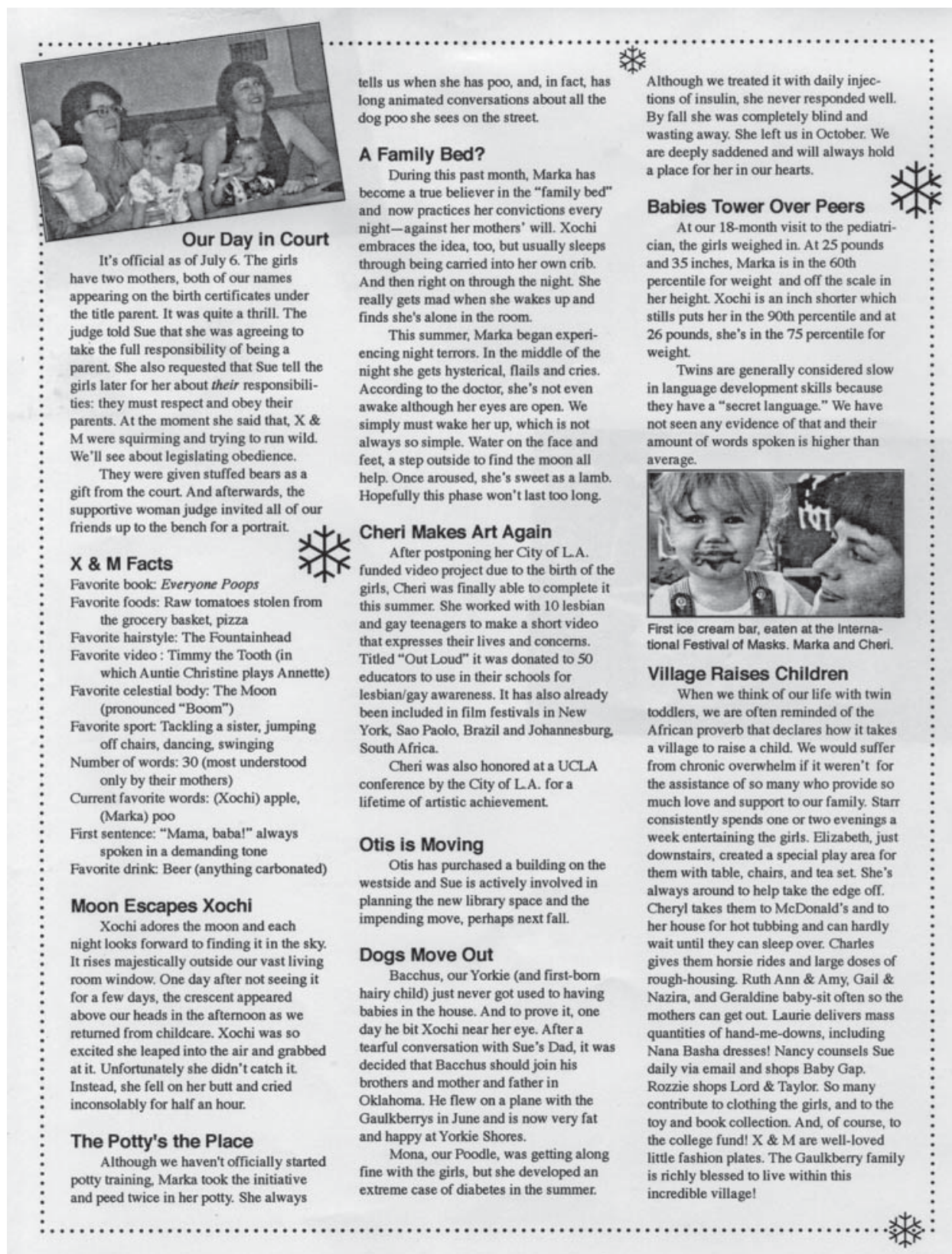

FIGURE 8 (Continued).

attraction and love between the parents, as conveyed through gestures, postures, and poses, became clearer. In the 2003 newsletter, the family's activities are presented in a single-spaced, one-page list, as opposed to the two-page earlier Gaulkeberry Gazettes. Kevin O'Malley, one of Gaulke's colleagues, photographed the family regularly and, in 2003, one of his images became 
the family's Winter Solstice/Christmas card (Figure 11). This card highlights the homosexuality of the parents in particular. The line "Don we now our gay apparel" in a gothic script runs across the top of the card as the first line of text so their queer status is made clear to the viewer.

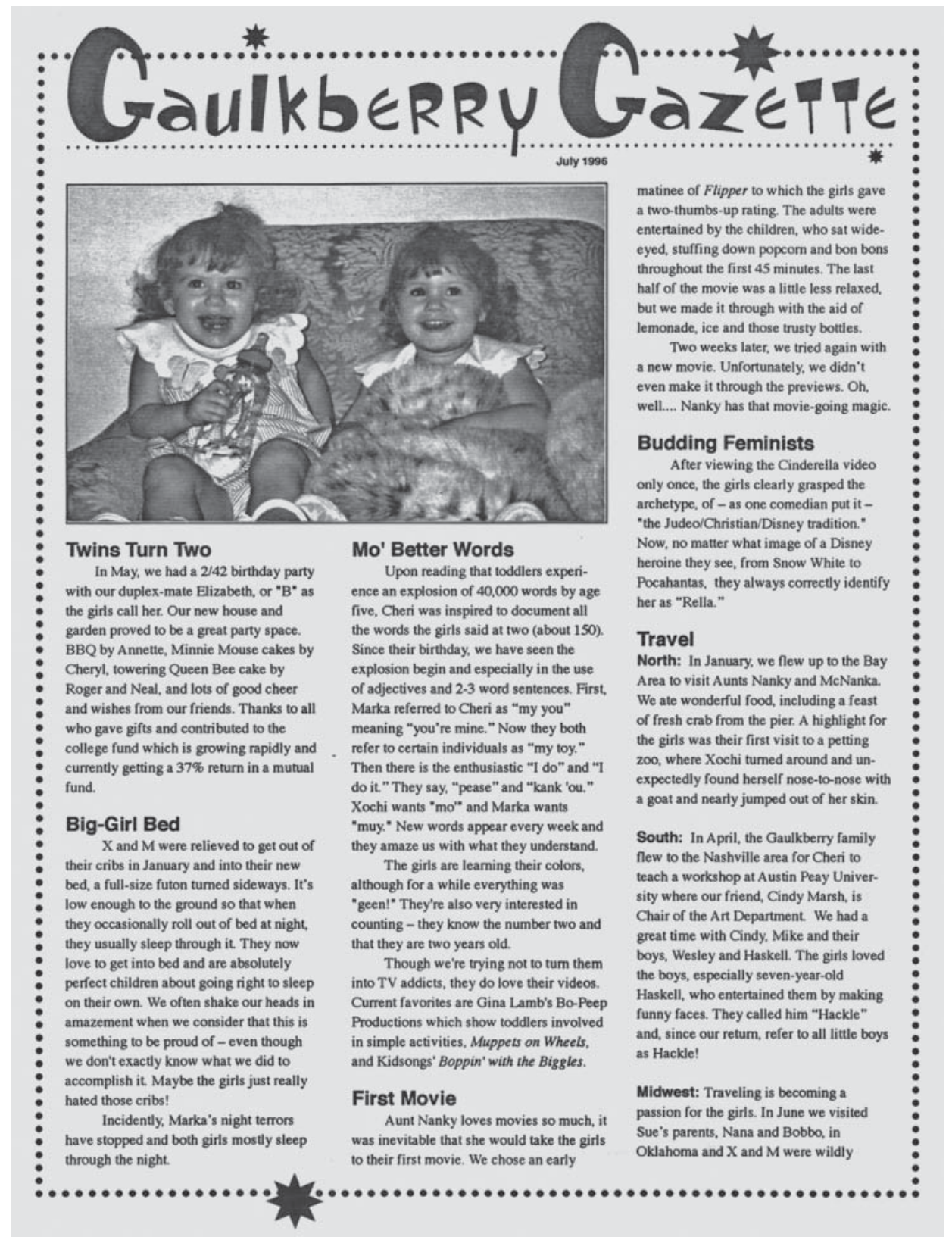

FIGURE 9 Cheri Gaulke and Sue Maberry, Gaulkberry Gazette, family newsletter, July 1996, double-sided document, photostatic copy, $8^{1} / 2 \times 11$ inches. (Reprinted with permission.) 


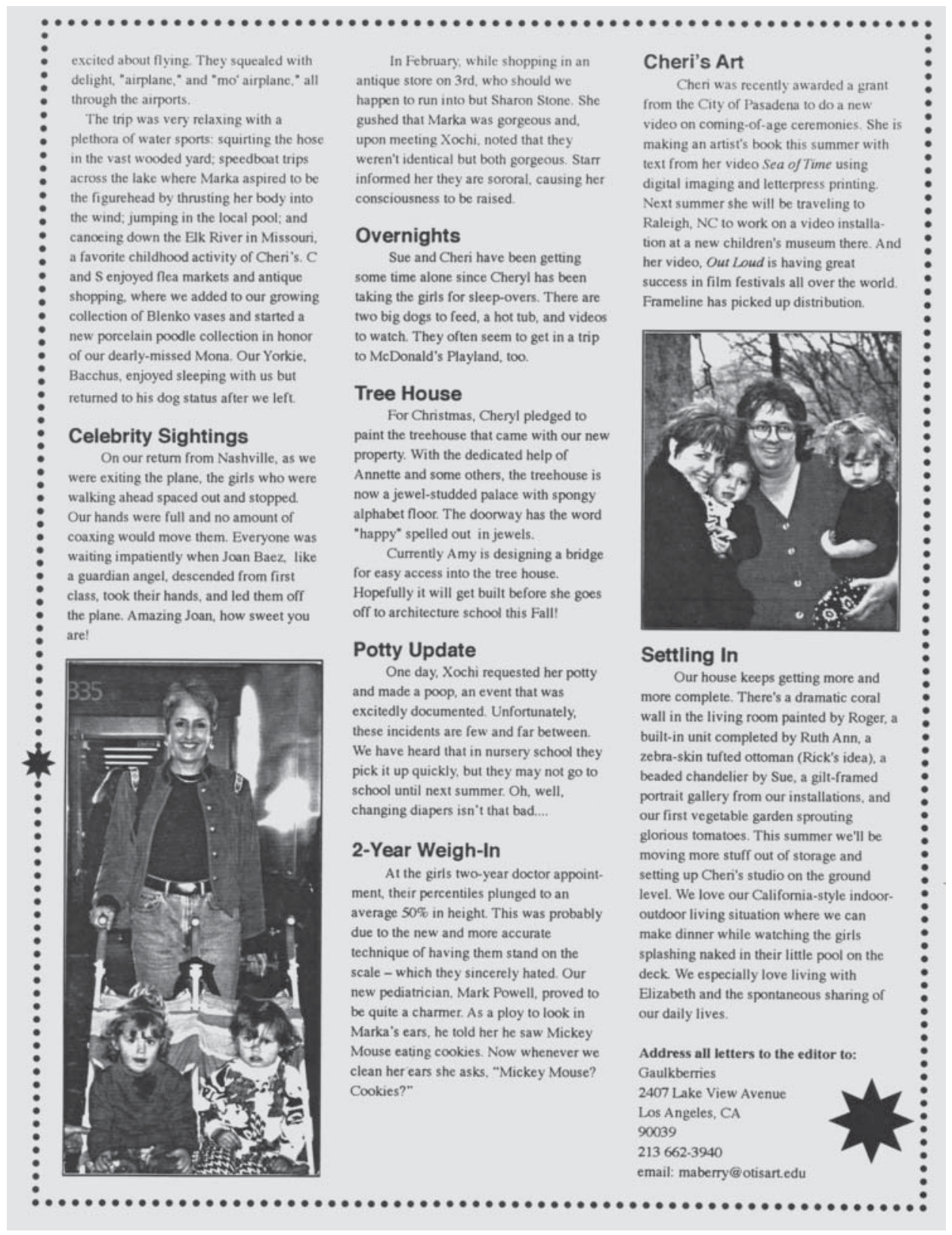

FIGURE 9 (Continued).

As an image of the family unit, this photograph is quite revealing of the evolution of the family dynamic and the composition of the family unit. Maberry touches Gaulke's waist, Xochi is behind Maberry, and Marka is above Gaulke; here, it is a little bit clearer that the parents are partners because of the configuration. In the past, the images produced showcased 


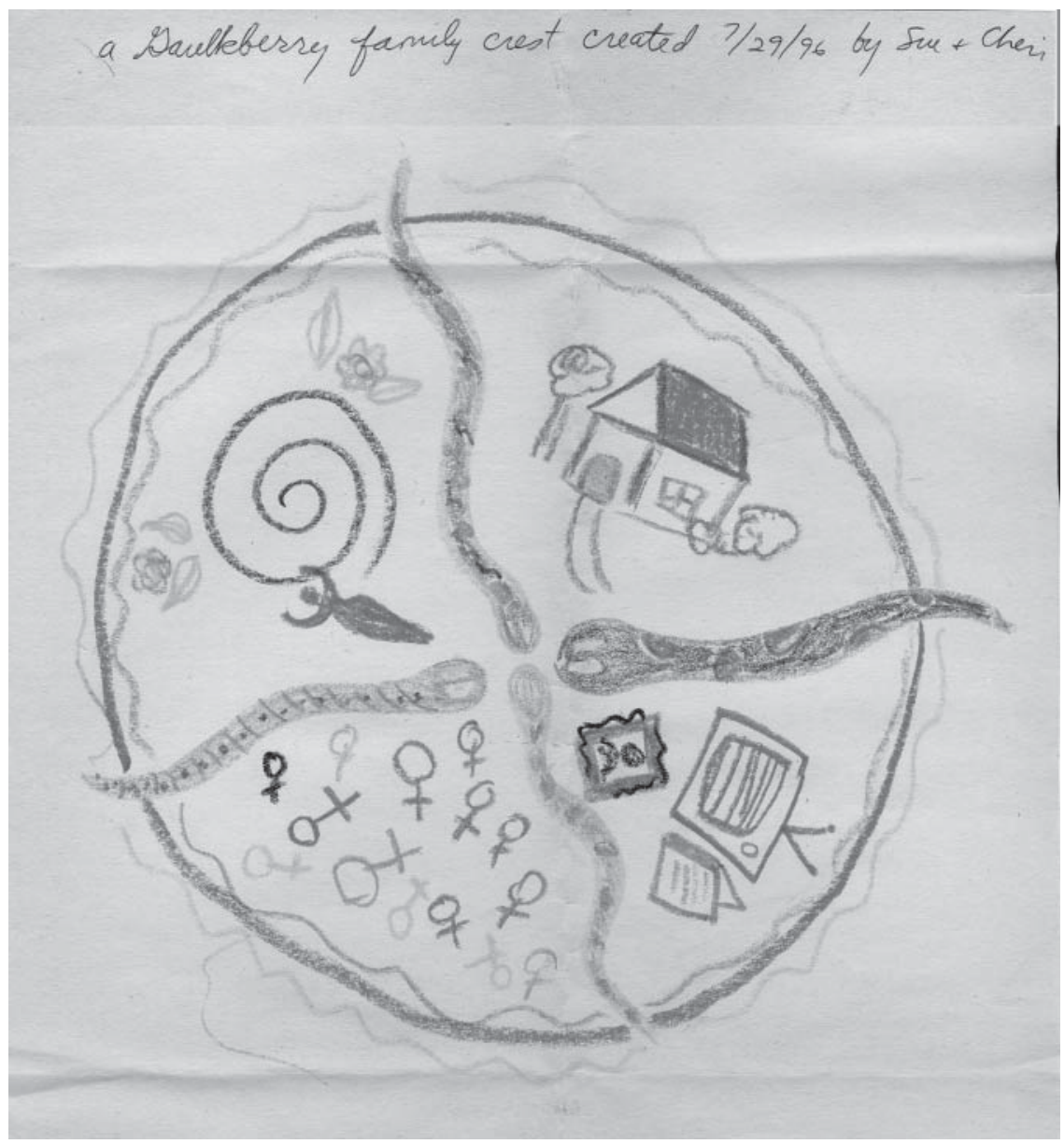

FIGURE 10 Cheri Gaulke and Sue Maberry, Gaulkberry Family Crest, 1996, drawing, crayon on paper, $8 \frac{1}{2} \times 11$ inches. (Reprinted with permission.)

the couple; the image of Gaulke and Maberry on the 1993 newsletter was the Sears-style portrait they had made for their 1992 artwork, Thicker Than Blood. But that earlier image does not readily suggest a sexual union since woman/woman photographs of that type suggest more kinship and companionship possibilities, everything from blood or sorority sisters (although the artists' age makes that one less likely, the pose is similar to such a relationship) to even simply friends. Andrea Liss has discussed the skillful manipulation of the Sears portrait in Gaulke and Maberry's work, as well as briefly considering the import of their representations of their family in ephemeral documents, such as the holiday newsletters (Liss, 88). Catherine Zuromskis argues for the importance of contextualizing vernacular images, such as the snapshots she discusses, within their social and value systems since unconventional images suggest alternatives to "social 
normativity and visual banality so often associated with snapshot [and portrait] culture[s]" (Zuromskis, 104). Her point applies to both the snapshots and portraits Gaulke and Maberry use in their art and in their newsletters and cards.

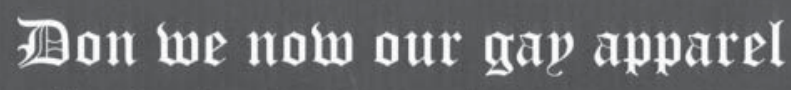
Ja la la la la la la la la

料

米

\section{Zlobe from the Gaulkberries}

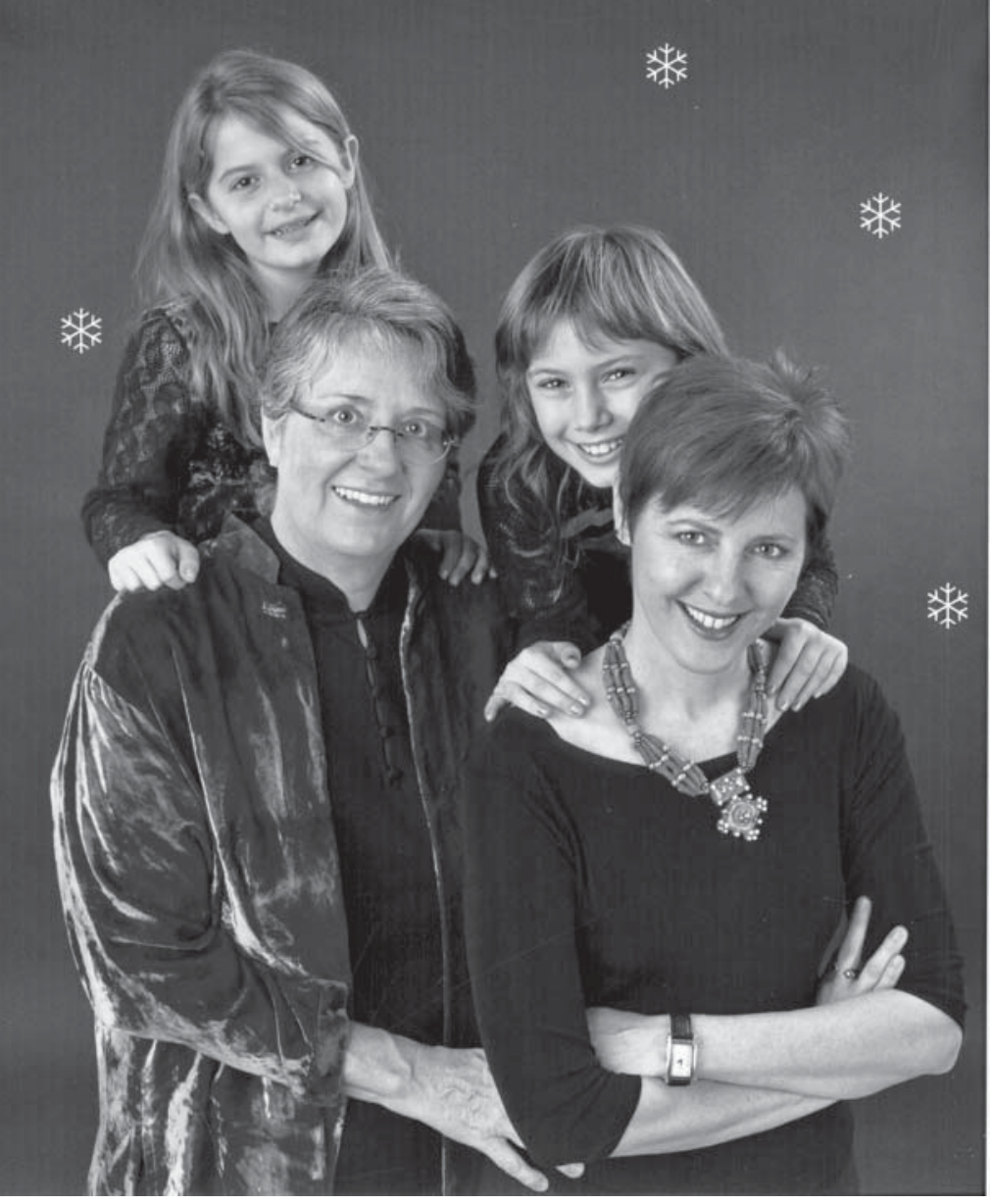

FIGURE 11 Cheri Gaulke and Sue Maberry, Winter Solstice/Christmas card and newsletter, 2003, with a photograph by Kevin O'Malley, two single-sided documents, inkjet prints, $5 \frac{1}{2} \times$ $8 \frac{1}{2}$ inches and $8 \frac{1}{2} \times 11$ inches. (Reprinted with permission.) 


\section{Gaulkberries 2003: 嫼ear in łhentem}

Minter

Maberry family throws big surprise dinner party / family reunion for Ann \& Bob's 50th anniversary. Limo ride was a highlight!

Sue joins YMCA and begins to exercise regularly.

A first: Sleep-away camp for X \& $M$ at de Benneville Pines, Presidents Day weekend.

Girls continue in Neighborhood UU Youth Choir with regular performances each month.

Girls continue in Jackie's dance class. Grace and skill developing well.

Sue attends Art Librarian conference in Baltimore.

Xochi gets braces.

Spring

Xochi performs in school play, "You're a Good Man, Charlie Brown."

Xochi performs in school play, "You're a Good Man, Charlie Brown."
Cheri takes book arts class at SF Center for Books Arts. Nice little family vacation.

Xochi takes up knitting.

Cheri's public art for Metro Rail Station is dedicated. Nancy Angelo cooks incredible food for celebration in our backyard. Xochi \& Marka turn 9 and visit Disney's California Adventures with Maberry grandparents.

Cheri \& Sue get older, too.

After two years of living with us to go to college, Dani moves out and spends summer with her family.

Xochi \& Marka get their own rooms and we all have fun redecorating them.

S)

Cheri to Prague and Vienna with Harvard-Westlake Chamber Singers to make video of trip.

Bob comes to stay and drives girls to summer camp daily.

Cheri's public art work for Lake View Terrace Library opens.

Girls go to church choir camp which culminates in a tremendous performance.

Sue \& Cheri officially register as Domestic Partners with the State of California.

Sue flies to RI for art school technology conference.

Kitchen remodel begins in July.

Gaulkberries learn many new places to eat out in Silverlake, but eventually tire of them all.

Lovely trip to S. Carolina coast with Gaulke family: long walks on pristine beaches, swimming with dolphins in bath-warm water,

endangered logger head turtle nests, noisy games of Cranium, delicious seafood meals with family.

Cheri's oral history is collected for UCLA artist archives.

Girls participate in USC twins study. Hate it!

Cheri joins Curves and commits to more regular exercise.

Sue gets new glasses.

\section{Ifall}

Xochi \& Marka discover 4th Grade is a LOT harder.

Dani transfers to Cal State L.A. and moves to dorm. Changes mind about majoring in biology.

Kitchen remodel continues, causing Gaulkberries enormous gnashing of teeth.

Sue signs up for another year of teaching Sunday School at Neighborhood UU Church.

She also joins Religious Education Committee.

Cheri still active in organizing Neighborhood CUUPS (Covenant of Unitarian Universalist Pagans).

Cheri, Xochi and Marka have a surf lesson one morning and the family sees James Brown at the Hollywood Bowl that night. A perfect Southem California day!

Cheri begins new project: documentary on ' 20 s child star Baby Peggy (now 86-years-old).

Sue goes to NYC to present on panel at the School for the Visual Arts.

Cheri gets new public art commissions -3 bridges over L.A. River.

We declare kitchen contractor "worst contractor in the world" and a few other things.

Halloween Trick or Treating gets rained out. Costumes: Xochi prom queen, Marka hula girl.

Cheri honored at dinner in NYC by Veteran Feminists of America.

Girls get their first report cards. All As for effort.

Marka performs song from Amistad with school choir and West Hollywood Orchestra.

Sue loses an additional 40 pounds over this year. $($ Total now $=60$ )

Kitchen remodel gets complete enough to have Thanksgiving dinner in new kitchen-11 dear friends join us including Sue's

parents and Cheri's cousin Karen and daughter Nicki.

Our colorful light-filled new kitchen (although still not finished!) now makes us happy every day.

Gaulkberries bake cookies in new convection oven and create holiday card, first time in 8 years!

FIGURE 11 (Continued).

In this image from 2003, the family members are all closely related in festive dress and expression as well as physically touching each other. It is significant to note how the gestures, gazes, postures, and poses, especially of the parents, indicate a relationship, even if only subtly, using 
heteronormalized cues in a lesbian context. Maberry, who is older, taller, and more imposing than Gaulke is on the left. Xochi's softer facial curves resemble Maberry's similarly more rounded jawline. Marka's lanky face visually resonates with Gaulke's more angular face as well. But it is the arm, Maberry's to be exact, which rests on Gaulke's hip that bespeaks a new direction in the family portrait for them. This gesture is not one friends make; it is one couples make. This image is not the first of the family, but it is the first where a gesture made between lovers is clearly in evidence. And it is unremarkable for the children above and behind them who have experienced much more intimate contact with their parents (see the discussion of " $\mathrm{A}$ Family Bed?" in the Winter Solstice 1995 newsletter for more details). Gaulke and Maberry have been quite direct about their status as lesbian parents. In the Summer 1995 newsletter, they mention "T.D.o.L. (Twin Daughters of Lesbians)," the exclusive "club" they formed with another lesbian couple with twins. Yet, this posture and pose is more evidence of their love for each other. The next generation is often pictured above in art historical conventions since the medieval period when prophets were often seen supporting apostles. So, here, the children are supported by their parents. Additionally, in the "Gaulkberries 2003: Year in Review" on the reverse, they recount "Sue \& Cheri officially register as Domestic Partners with the State of California." It also mentions Gaulke's involvement in organizing a Neighborhood CUUPS (Covenant of Unitarian Universalist Pagans) that honors goddess-based, earth-centered, tribal, and pagan spiritualism; Sue is noted as continuing to teach Sunday School at their local church.

And the images continue to become more explicit about the parents' lesbianism. The pace of life reduced the amount of text on the 2004 winter card (Figure 12) to a "Highlights of 2004," which was really a single paragraph of text on this single-sided card. Of the seventeen images on the card's face, four are of the parents, one is of the whole family, and the rest are of Gaulke with the children or one of Gaulke alone. In these four images, the artists are posed conventionally as a couple for travel photographs, adjacent to a setting for an exotic location. Marka is in physical contact with Gaulke and Maberry in one of the images where she and Xochi appear with their parents and Gaulke in another with Xochi. The family is interlaced literally by Maberry reaching across to hold Marka's hand, while the child stands in front of Gaulke. The sexual relationship of the couple is much more obvious in these images, as is the abundance and prosperity both materially (foreign and domestic travel are a central part of the family life, a promise the parents had made to the children at their naming ceremony) and emotionally (the family engages in a wide range of leisure activities together). Additionally, the lesbianism of the parents is most in evidence in the image of the children attending their first marriage equality parade, a "Freedom to Marry" march and rally in the family's Silver Lake neighborhood of Los Angeles. Gaulke writes about this experience in Marriage Matters: 


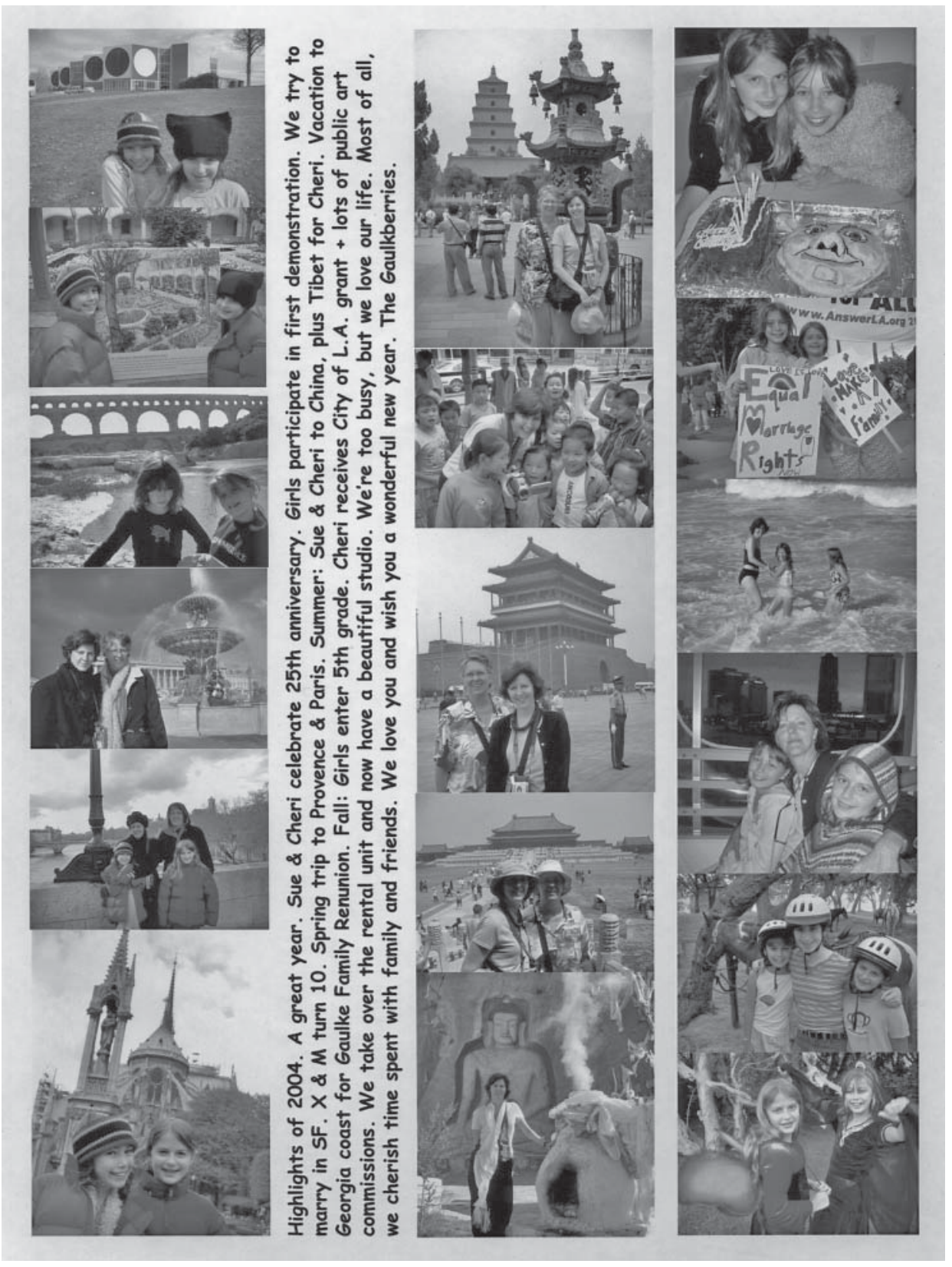

FIGURE 12 Cheri Gaulke and Sue Maberry, Winter Solstice/Christmas card with written information, 2004, single-sided document, inkjet print, $8 \frac{1}{2} \times 11$ inches. (Reprinted with permission.)

It would be Xochi and Marka's first protest rally. We encouraged them to make signs to carry. A delicate process, we wanted to politicize them but not be too pushy. Ironically, the sting of prejudice so prevalent in our lives was not really cognizant for them. We had carefully placed them in 
schools, a church, and a neighborhood where their family was generally recognized and accepted. They don't have the same anger at the injustice that we do, nor a sense of history. ... Xochi came up with "Love Makes a Family." Marka's sign said "Equal Marriage Rights Now" and next to a rainbow she added simply "Love is Love." ... When we arrived at the march, the girls were a little embarrassed because they were the only ones with hand-made signs. Soon they became the darlings of the media and photographers were snapping their pictures. As the march began, they stepped proudly into the front lines. (Gaulke and Maberry 2005, 8)

The visibility of the Gaulke/Maberry family has shifted with this card as the images show the children politicized and also loved, as the parents' love continues to define the family experience as the activities become more diverse and the children become increasingly independent. The next two years' cards are less focused on the parents as a couple. In 2005 (Figure 13), none of the twenty-five images show the couple, although as an indicator of their involvement in pagan practices, mention is made of their Goddess daughter Daniela. In 2006 (Figure 14), two of the sixteen images show all

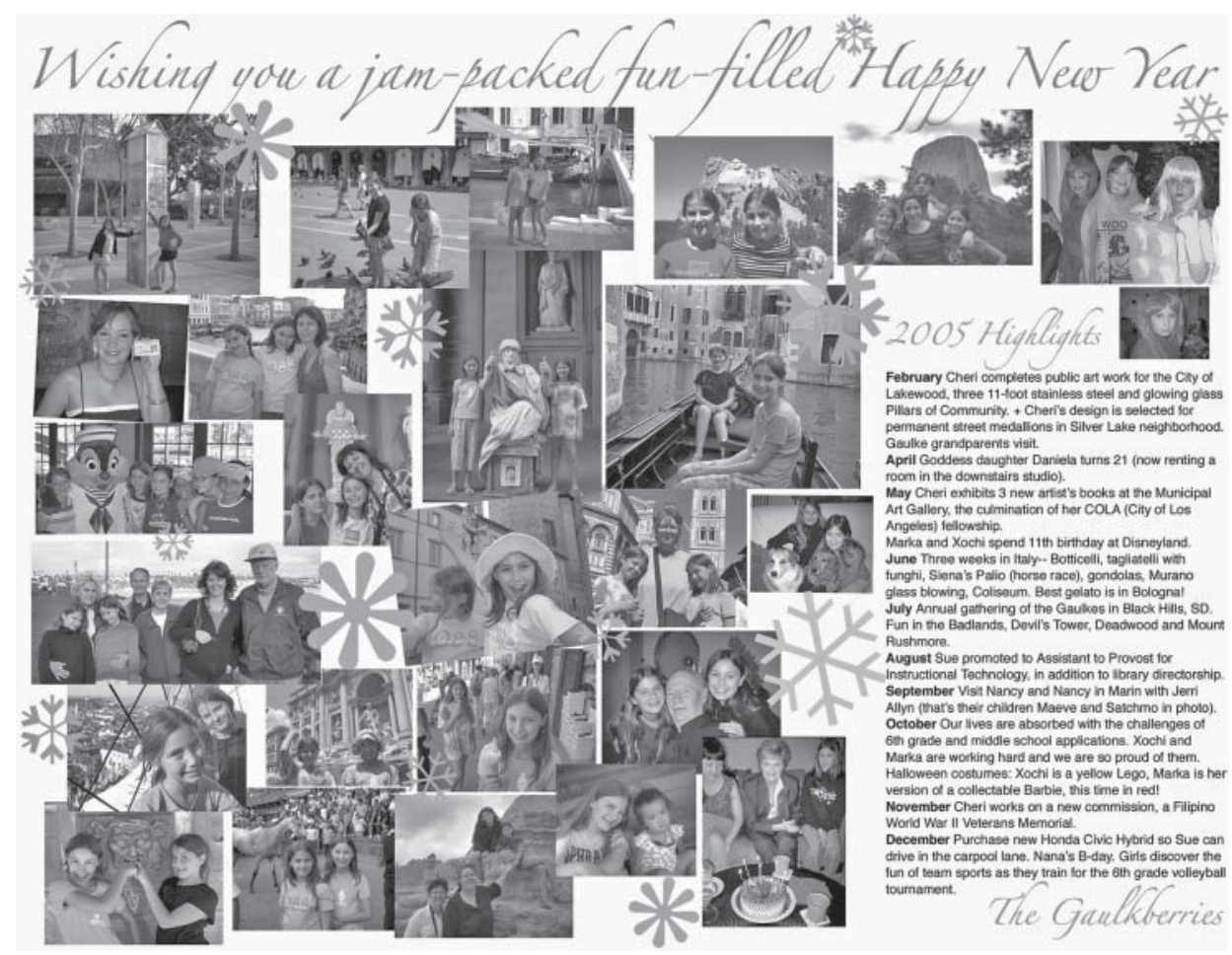

FIGURE 13 Cheri Gaulke and Sue Maberry, Winter Solstice/Christmas card with written information, 2005, single-sided document, inkjet print, $8 \frac{1}{2} \times 11$ inches. (Reprinted with permission.) 


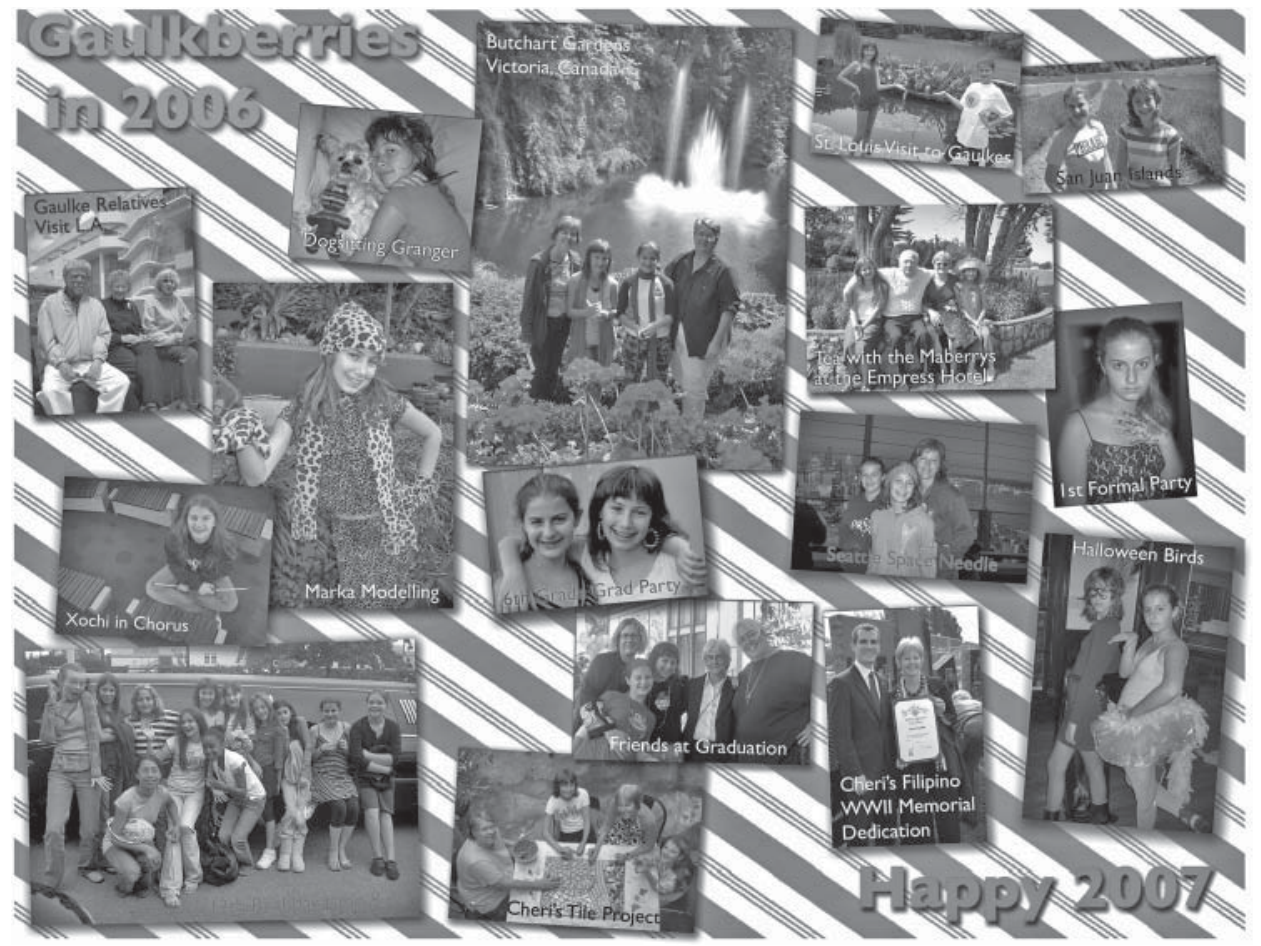

FIGURE 14 Cheri Gaulke and Sue Maberry, Winter Solstice/Christmas card with written information, 2006, single-sided document, inkjet print, $8 \frac{1}{2} \times 11$ inches. (Reprinted with permission.)

four family members, but there are no images of just the couple. One of the images includes three adult women family friends with the twins, but they stand as friends with no intimate gestures of affection between the adults.

The 2007 and 2008 cards are visually uncomplicated-fewer images and simplified edges between photographs (Figures 15 and 16). Gaulke and Maberry reduced the number of images on their 2007 card with a brief listing on the reverse of information chronologically listed by month. Of the eight images, two are of the entire family with Gaulke and Maberry standing in close proximity. The two women and two girls stand together, arranged in the conventions used for family travel photographs (both of these particular images were taken on a family trip to Alaska). These photographs are close up with all of them appearing either in the foreground-forward picture plane-or the middle ground. For a brief period in 2008, marriage was an option for gays and lesbians in California, which Gaulke and Maberry reference in their card with two photographs from their wedding (one as a couple and one with the children and other relatives) and the transformation of the zeros in 2008 into intertwined, highlighted wedding rings from their July wedding. In June, the twins participated in a coming-of-age rite of 


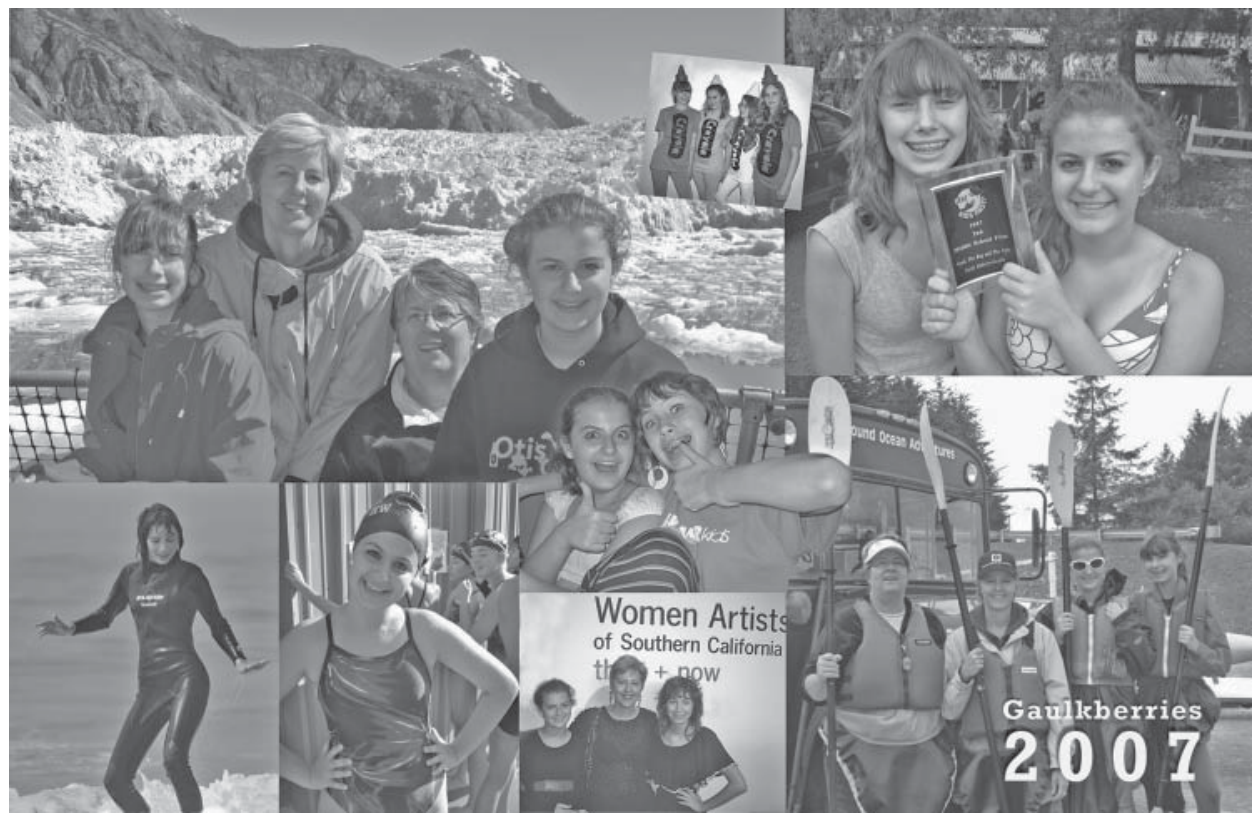

\section{Gaulkberry Gazette}

JAN Marka dances in school concert 2407 Lake View Ave. Los Angeles, CA 90039

Weekend Family Camp in San Bernardino Mociation in NYC

FEB Cheri on panel at Clack Like We show at Harvard-Westlake Cheri organizes Black Like We show trip to Las Vegas

APR Gaulkes come to visit \&

MAY Xochi \& Marka goes to Surf Camp

JUN Marka goes to Surcellence Award Sue \& Otis team win NMC Centers of art exhibitions Cheri in feminist and environmental art

Gaulke Family Reunion in Door County, Wisconsin

AUG Cheri's Filipino WWII Memorial book published

SEP X \& M start 8th Grade with great group of friends

Xochi joins the Swim Team which wins 3rd place

OCT $\mathrm{X} \& \mathrm{M}$ are Crayons for Halloween

NOV $X \& M$ win 2nd Place in Kid's First! film festival

DEC Spend the holidays with the Maberrys in Calimesa

The photos make us look like a very sporty family.

We ARE actually trying to exercise often and eat more vegetables...

\section{Wishing you a joyous, healthful 2008!}

Love from Cheri, Sue, Xochi \& Marka

FIGURE 15 Cheri Gaulke and Sue Maberry, Winter Solstice/Christmas card with written information, 2007, double-sided document, offset print, $5 \frac{1}{2} \times 8^{1 / 2}$ inches. (Reprinted with permission.) 


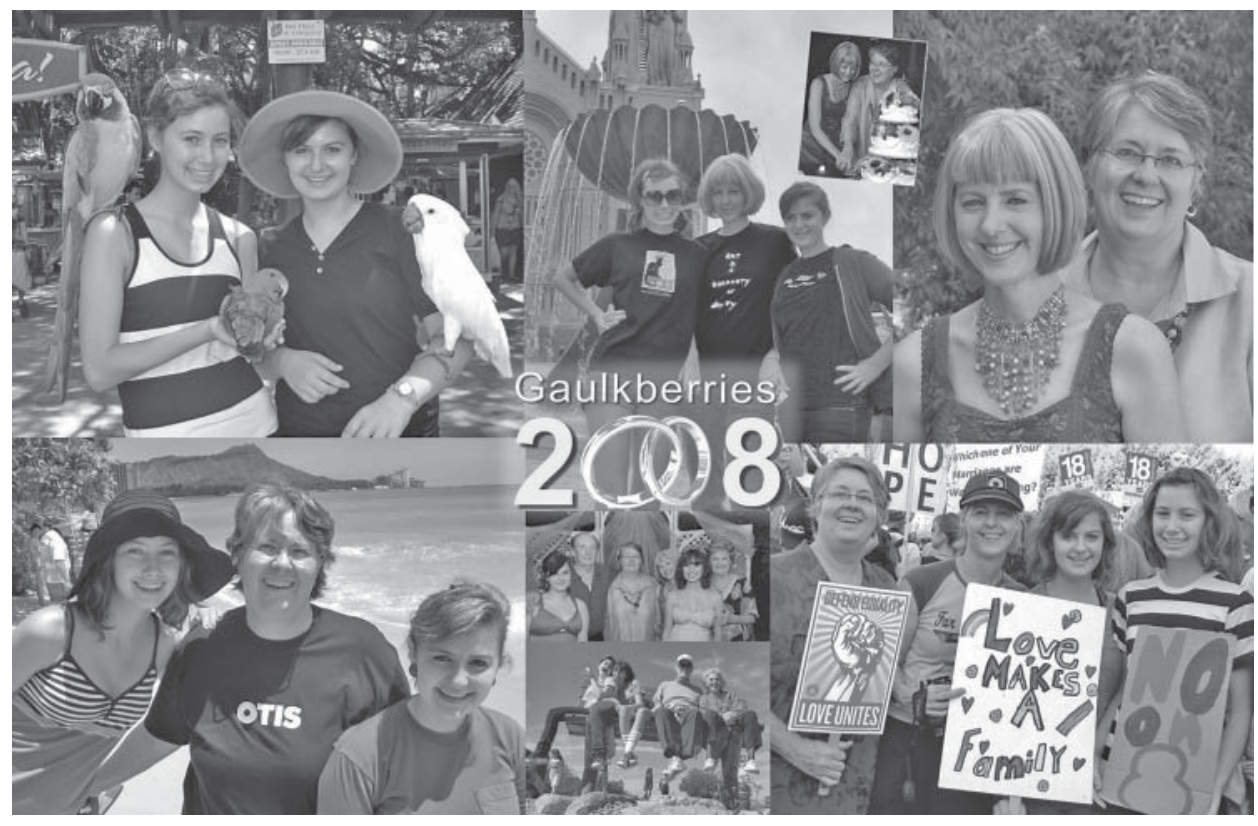

\section{Gaulkberry Gazette}

JAN The passing of our dear friend Susan Gray and Cheri's colleague Carl Wilson

Maberry-Gaulke Family 2407 Lake View Avenue Los Angeles, CA 90039

MAR C \& $S$ create videos for Bronx Museum historic feminist art exhibit Cheri and Sue celebrate their 29th year together Gaulke grandparents visit LA

MAY Sue speaks at art librarian conference in Denver Cheri shows 1976 video at Getty Museum $X \& M$ turn 14

JUN $\quad X \& M$ give Rites of Passage speeches at our UU church $X$ \& $M$ make a film in Cheri's HW Film Camp

JUL Cheri and Sue LEGALLY marry!

Travel to NYC, then Gaulke Family Reunion in French Canada

AUG Gaulkberry's first vacation in Hawaii (Waikiki and Hilo)

SEP C becomes Art Dept. Chair at Harvard-Westlake, X \& M start 9th Grade

OCT Glass sculpture by Cheri dedicated at Neighborhood Church $X \& M$ canoe down Colorado River on school retreat NOV Prop. 8 passes, Gaulkberries protest with the masses

DEC Cheri travelling to Ethopia to work with youth making a film about the impact of wells on girls' lives.

$X \& M$ and Sue spending holidays with Maberrys and then driving with Jerri to SF area to visit the Nancys.

\section{Wishing you a 2009 filled with love.}

May the civil rights promised in the founding of our country finally be expanded to include all of us.

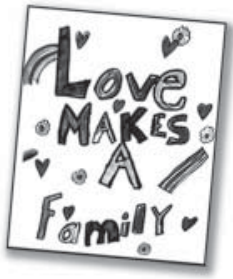

Love from Cheri, Sue, Xochi and Marka

FIGURE 16 Cheri Gaulke and Sue Maberry, Winter Solstice/Christmas card with written information, 2008, double-sided document, offset print, $5 \frac{1}{2} \times 8 \frac{1}{2}$ inches. (Reprinted with permission.) 
passage at their church. Additionally, the family appears in a group portrait at a protest rally against the passage of Proposition 8 , the anti-marriage equity bill in California, with Xochi's sign from the family's participation in the 2003 protest reappearing both in Xochi's hands at the rally and also reproduced

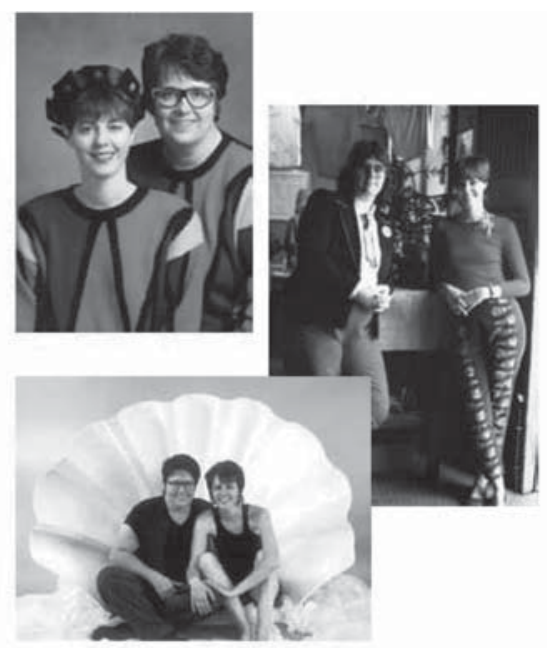

Love and Wor ship

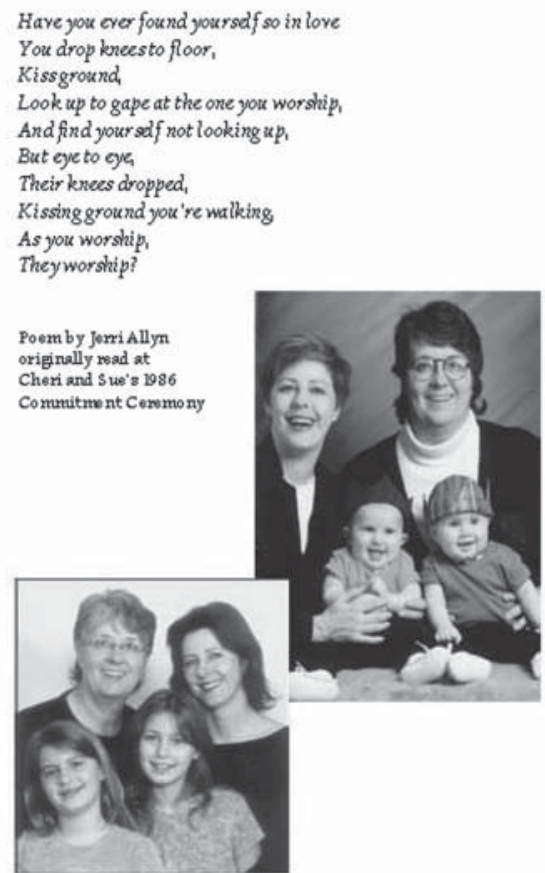

\section{Program}

\section{Pre-ceremony}

You are invited to adorn our wedding arch

with a wish and a sunflower

Processional

Original song by Phranc

Welcome and Remarks

Reverend Hannah Petrie

Goddess Blessing

Words by Susan Gray

Reading by Starr Goode

A History of Love

Jerri Allyn, Ruth Ann Anderson, Susan Boyle, Kathleen Forrest, Anne Gauldin, Starr Goode, Lianna Nakashima, Christine Papalexis

Love and Worship

Jerri Allyn

Vows

Cheri and Sue

Affirmation

Marka and Xochi Maberry-Gaulke

Exchange of Rings \& Pronouncement

Recessional

Reception to follow

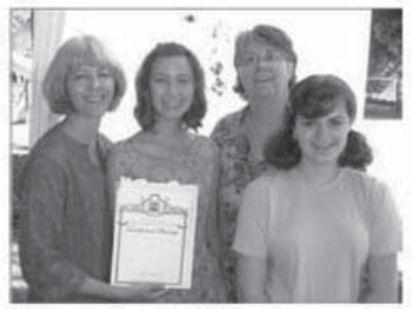

FIGURE 17 Cheri Gaulke and Sue Maberry, Wedding Program, 2008, double-sided document, color laser print, $8 \frac{1}{2} \times 11$ inches. (Reprinted with permission.) 
Please visit the video booth in the Narthex, organized by John Glouchevitch and Lizzie Barcay. All are encouraged to record thoughts about samerex marriage which will become part of a future artwork by Cheri and Sue.

Acknowledgements

We are grateful to all of you, our friends, fam ily. coworkers, and spiritual communities who have supported our relationship and family over many years, with special thanks to...

Reverend Hannah Petrie and Neighborhood Church for standing on the side of love

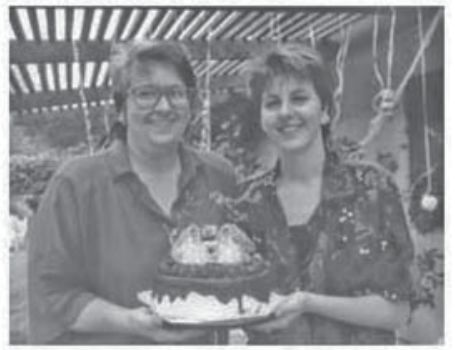

Our sisters of Nemesis for the rituals of our lives

Phranc for performing heroriginal song

A Celebration of Love, Everyone for sharing generous gifts of food

Cheryl Revkin, potluck organizer and Queen of Com posting. Go ahead and eat your fork!l't's made of potatoes. In fact, all of our dinnerware is made of compostable materials. Cheryl and hd pers will transport our food waste and dinnerware to special composting bins at Gin ger Grass restaurant in Silver Lake.

Gail Ivens, Mistress of Lists and Bevera ges. If shetires of thelaw, shecould become a weding planner.

Parme and Paul Giuntini who provided the exquisite wedding cake

Sheila Siegel for flower arran gements, Christine Papalexis for decorations, Ruth Ann Anderson and Anne Gauldin for the sunflower blessing ritual

Kevin O'Malley, Allan Sasaki, and Les Nakashima for photo graphy, David Jacks for audio, Anne Gauldin and Spectrum Digital for photo blowups

... and the many others who helped make this day possible.

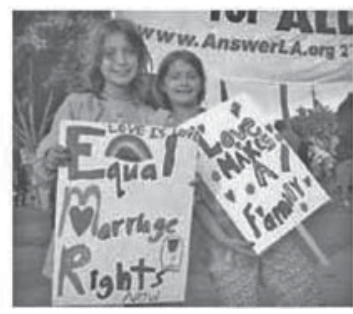

We need your support

to keep

same-sex

marriage

legal.

\title{
Family o Community
}

\author{
The LEGAL Marriage of \\ Sue Maberry \& Cheri Gaulke
}

Saturday, July 5, 2008

Neighborhood Unitarian

Universalist Church

Pasadena, California

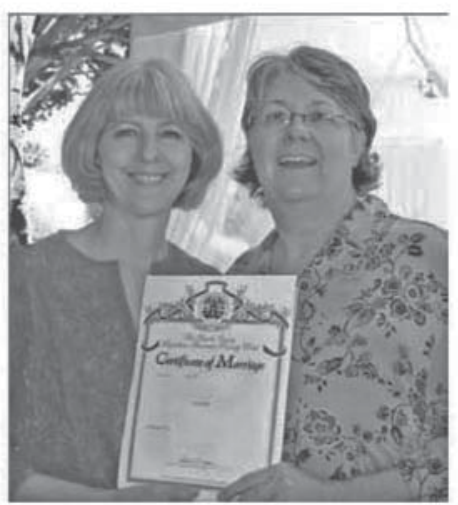

Vote in

November.

FIGURE 17 (Continued).

on the back of the card. At the end of the year, a visit to the Nancys is recounted (which had been noted in July 1996 and on the 2005 card). The final wish from the family is heartening in its optimism: "Wishing you a 2009 filled with love. May the civil rights promised in the founding of our country 
finally be expanded to include all of us." In their Wedding Program of 2008 (Figure 17), five images of the couple appear alongside three family portraits with a reappearance of the twins with the 2005 image of them holding their marriage equity signs. In addition, they offered guests a chance to enter a video booth and "record their thoughts about same-sex marriage which will become part of a future artwork by Cheri and Sue."

\section{CONCLUSION}

Gaulke and Maberry's feminist activism combined with their lesbianism, radicalized them to create ongoing documentation of their family. I find them exciting and joyful because of the magnificence with which they celebrate their family love. These documents form a narrative about the evolution of lesbian self-representation at a time when homosexuality remains a volatile subject. That Gaulke and Maberry have persisted in creating a strong family unit is a testament to their survival skills. That their visual and verbal documents are so powerful is a testimony to their abilities to be socially active as artists. The discursive space of their text and images offer some examples for visualizing a lesbian family using the heteronormalized conventions of family documentation while asserting their queerness and happiness. Their love and community grew out of their experiences in the early days of feminist art at the Woman's Building, a tribute to both the sustaining principles of that institution and its founders' ideals and to the public and private passions of these two artists. By internalizing the rhetoric of heterosexuality while asserting their lesbianism, the artists have created teleological emblems of the lesbian family that speak beyond the confines of their private experience to the broader domain of lesbian self-representation.

\section{NOTES}

1. I call Maberry an artist throughout this article because she and Gaulke have often collaborated on making visual images (and verbal narratives) of their lesbian family. Maberry clarified for me that she does not regard herself as an artist per se, remarking, "I make art, but I don't really identify that much as an artist. I'm just not driven enough" (Maberry 2009).

2. More recently, she transitioned to making public art because it fulfilled her desire for art with more permanence and more freedom with her teaching and family responsibilities.

3. "WACK: Art and the Feminist Revolution" was curated by Cornelia Butler at the Museum of Contemporary Art in Los Angeles. It traveled to Washington, DC; New York; Vancouver; and Paris.

4. All images are in the artists' collection, unless otherwise noted, and are reproduced with permission.

\section{REFERENCES}

Aguilar, Laura. 2009. Telephone conversation, April 27.

Allyn, Jerri. 2009. E-mail to author, March 18. 
Carlson, Marcia J., and Mary E. Corcoran. 2001. "Family Structure and Children's Behavioral and Cognitive Outcomes." Journal of Marriage and the Family 63, no. 3 (August), 779-792.

Gaulke, Cheri. 1992/2007. Interview by Michelle Moravec. Woman's Building Oral History Project, 6 August 1992, Los Angeles, CA. In Laura Meyer, "The Woman's Building and Los Angeles' Leading Role in the Feminist Art Movement." [From Site to Vision]: The Woman's Building in Contemporary Culture. Sondra Hale and Terry Wolverton, eds. Los Angeles: The Woman's Building, Inc., 2007, 91. (http://womansbuilding.org/fromsitetovision/pdfs/Meyer.pdf) (accessed March 20, 2009).

Gaulke, Cheri. 2009a. E-mail to author, March 8.

Gaulke, Cheri. 2009b. E-mail to author, March 10.

Gaulke, Cheri. 2009c. E-mail to author, March 20.

Gaulke, Cheri. 2009d. E-mail to author, March 31.

Gaulke, Cheri, and Sue Maberry. 1995. Artists' Statement, Families Next Door, mixedmedia installation, in "Community Properties," Huntington Beach Art Center.

Gaulke, Cheri, and Sue Maberry. 2005. Marriage Matters (written by Gaulke; designed by Gaulke and Maberry), 2005, edition of fifty, color laser print on paper, arranged in the form of a three-dimensional wedding cake, unpaginated (pages 1-9).

Grover, Jan Zita. "Dykes in Context: Some Problems in Minority Representation.” In The Contest of Meaning: Critical Histories of Photography. Ed. Richard Bolton. Cambridge: The MIT Press, 1992. 163-197.

Hammond, Harmony. 2000. Lesbian Art in America: A Contemporary History. New York: Rizzoli International Publications.

Klein, Jennie. "Queering Birth and Death: Cheri Gaulke's and Sue Maberry's Sea of Time," 2009, unpublished manuscript.

Lesbian History Group. 1993. Not a Passing Phase: Reclaiming Lesbians in History, 1840-1985. London: Women's Press.

Liss, Andrea. 2009. Feminist Art and the Maternal. Minneapolis: University of Minnesota Press.

Lord, Catherine. 1995. Pervert: The Art Gallery. Irvine, CA: The Gallery P.

Maberry, Sue. 2009. E-mail to author, March 10.

Mahon, Alyce. 2005. Eroticism and Art. Oxford: Oxford University Press.

Mavor, Anne. 1996. Strong Hearts, Inspired Minds: 21 Artists who are Mothers Tell Their Stories. Portland, OR: Rowanberry Books.

Meezan, William, and Jonathan Rauch. 2005. "Gay Marriage, Same-Sex Parenting, and America's Children." The Future of Children 15, no. 2 (Fall), 97-113.

Meskimmon, Marsha. 1996. The Art of Reflection: Women Artists' Self-Portraiture in the Twentieth Century. New York: Columbia University Press.

Rich, Adrienne. 2003. "Compulsory Heterosexuality and Lesbian Existence." Journal of Women's History 15, no. 3.

Swartz, Anne. 2009. "Interview with Cheri Gaulke and Sue Maberry in their Los Angeles, California home," February 26.

Wolverton, Terry. 2002. Insurgent Muse: Life and Art at the Woman's Building. San Francisco, CA: City Lights Books. 
Woman's Building website (http://womansbuilding.org/history.htm) (accessed March 2, 2009).

Zuromskis, Catherine. 2008. "Ordinary Pictures and Accidental Masterpieces: Snapshot Photography in the Modern Art Museum." Art Journal 67, no. 2 (Summer): $104-24$.

\section{CONTRIBUTOR}

Anne Swartz is a Professor of art history at the Savannah College of Art and Design. She lectures widely on contemporary art and art criticism, has published many exhibition catalogs, and authored numerous articles in journals and periodicals. 